\title{
RNAi in Clinical Studies
}

\author{
P. Kubowicz ${ }^{1}$, D. Żelaszczyk ${ }^{2}$ and E. Pękala* ${ }^{1}$
}

${ }^{1}$ Department of Technology and Biotechnology of Drugs, Faculty of Pharmacy, Jagiellonian University Medical College, 9 Medyczna Street, 30-688 Krakow, Poland; ${ }^{2}$ Department of Bioorganic Chemistry, Chair of Organic Chemistry, Faculty of Pharmacy, Jagiellonian University Medical College, 9 Medyczna Street, 30-688 Krakow, Poland

\begin{abstract}
RNA interference (RNAi) is an efficient process of posttranscriptional gene silencing. In recent years it has been developed into a new technology in biopharmaceutical fields of science. RNAi products include short interference RNA (siRNA) but also short hairpin RNA (shRNA), bifunctional short hairpin RNA (bi-shRNA) and microRNA (miRNA). They combine with homologous fragments of the mRNA and cause its degradation. It results in inhibition of protein synthesis, or in mutation in the gene encoding it. RNAi has been used in analysis of genomes and creation of new animal models to test drugs. From the pharmaceutical point of view, what is the most important is its therapeutic application. So far the basic and clinical research has been focused on the following targets: macular degeneration, cancer and antiviral therapy. But there are also reports on clinical trials in asthma, hypercholesterolemia and genetic diseases such as inherited skin disorders and amyloidosis. Among over 20 therapeutics that reached clinical trials, only few are still investigated. Another few are clinical candidates. The review focuses on RNAi products under clinical evaluation and their most promising new applications.
\end{abstract}

Keywords: Cancer, clinical trials, miRNA, post-transcriptional gene silencing, RNA interference, RNAi-based therapies, siRNA.

\section{INTRODUCTION}

The rapid development which has been visible in all fields of biology, particularly biochemistry and genetics, for several years now has produced successful results contributing to the explanation of a number of biological processes. One of the greatest achievements was the explanation of the mechanism of gene expression in eukaryotes and how this mechanism is controlled. This discovery, which has revolutionized the research of gene expression, was RNA interference (RNAi) [1]. The authors of this discovery - Andrew Fire and Craig Mello - were honored with the Nobel Prize in Medicine and Physiology in 2006. The results of their research on the mechanism of RNA interference were published in 1998 in Nature [2]. This discovery has opened new perspectives for researchers. It allows them to explore the gene function through the inhibition of gene expression. The phenomenon of RNA interference aroused the hopes of many biotechnological and pharmaceutical companies to develop a new generation of effective drugs, a personalized gene therapy for cancer among others. The aim of this review was to present the newest information about RNAi therapeuticals which are currently in clinical trials.

\section{MECHANISM OF RNA INTERFERENCE ACTION}

The process of RNA interference was originally called PTGS - post-transcriptional gene silencing [3, 4]. However,

\footnotetext{
*Address correspondence to this author at the Department of Technology and Biotechnology of Drugs, Faculty of Pharmacy, Jagiellonian University Medical College, 9 Medyczna Street, 30-688 Krakow, Poland; Tel: 0048 126205598; Fax: 0048 126205405; E-mail: elzbieta.pekala@uj.edu.pl
}

regardless of the name, this process enables the specific degradation of target mRNA by using dsRNA (double-stranded RNA). It allows the inhibition of gene expression.

RNAi plays a major role in regulating eukaryotic gene expression. There are two classes of particular interest $\approx 22$-nt RNAs that can be further subdivided into siRNAs and miRNAs Fig. (1) siRNAs are double-stranded RNAs, which are transcribed endogenously or introduced into cells by viral infection or transfection [5].

siRNA pathway (step 1-7) Fig. (1): long double stranded RNA (dsRNA) as well as transcribed in the nucleus short hairpin RNA (shRNA) (1) are recognized and processed by Dicer, an RNase III enzyme, into duplexes of short interfering RNA (siRNA) of 21 to 24 nucleotides in length (2). Then endogenous siRNAs or synthetic siRNAs (3) can also be incorporated into the RNA-induced silencing complex (RISC) (4). A helicase in RISC unwinds the duplex siRNA (5), which then pairs to the target messenger RNAs (mRNAs) with a high degree of sequence complementarity to the siRNA (6). An unidentified RNase (Slicer) within RISC degrades the mRNA at sites not bound by the siRNA (7).

miRNA pathway (step 8,9,2,4-6,10) Fig. (1): the genes encoding miRNAs are transcribed to produce the primary miRNA (pri-miRNA) (8). The dsRNA-specific ribonuclease digests the pri-miRNA in the nucleus to form another precursor miRNA - pre-miRNA - which is exported to the cytoplasm (9). Like siRNAs, miRNAs are processed by Dicer creating the mature miRNA (2), one strand of which is incorporated into a ribonucleoprotein complex, which is simi- 


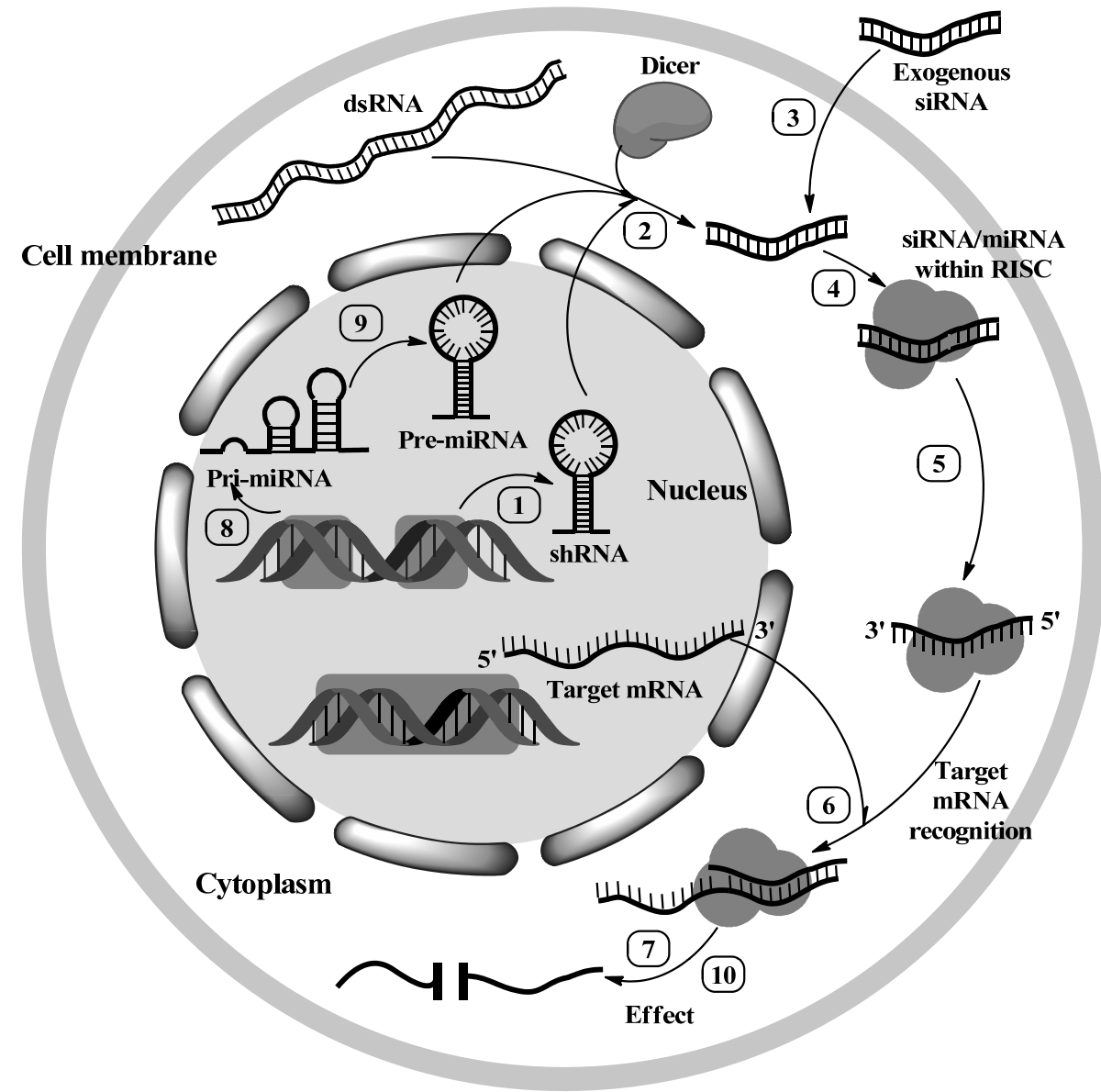

Fig. (1). Mechanism of siRNA and miRNA action $[5,6]$.

lar, if not identical, to RISC (4). It unwinds the duplex miRNA (5). Base pairing between the miRNA and its target (6) directs RISC to either destroy the mRNA or attenuate its translation into protein (10).

The gene silencing process performed in insects and plants by endogenous siRNA may be divided into two stages. In the first stage, long, double-stranded RNA (dsRNA) is recognized and cleaved by cytoplasmic ribonuclease III (RNase III) - like protein known as Dicer, which is responsible for cleaving double stranded nucleic acid derived from replicating viruses [7, 8]. Short interfering doublestranded siRNAs with a length from 19 to 25 base pairs (bp) are formed in the digestion process conducted by Dicer. Such siRNA has 3'-dinucleotide overhangs and 5'-phosphate groups [9].

In the second stage siRNA connects to the RISC (RNAinduced silencing complex), where ATP-dependent helicase unwind the duplex. What is very important considering the gene therapy, synthetic siRNA introduced into cells can be also incorporated into the RISC complex. The RNA helicase activity of the RISC complex untangles siRNA to singlestranded form, and removes one of the strand [10]. The single siRNA strand located in the RISC (guide strand) is used to find complementary mRNA sequences in the cytoplasm. Ago2 protein (Argonaut family) is responsible for the hydrolysis of phosphodiester bond in mRNA (complementary to the guide strand in RISC complex) [11]. to the guide strand in RISC complex) [11]. siRNA is able to cleave target RNA in both the cytoplasm and the nucleus. It was shown that the established, active RISC complex does not dissociate after hydrolysis of one molecule of mRNA, but catalyzes the subsequent reaction, which contributes to the high efficiency of RNAi mechanism [12].

Another RNAi is shRNA. shRNA is a molecule which has a short loop sequence between the two complementary strands. The expressed shRNA is exported into the cytoplasm where it is processed by Dicer into siRNA [13].

miRNAs are also a member of the RNAi family. The naturally occurring miRNAs are synthesized in the nucleus in large precursor forms. The enzyme known as Drosha mediates the processing of the primary miRNA transcripts into pre-miRNAs, which are then exported to the cytoplasm [14]. Mature miRNAs are dependent on Dicer for appropriate processing and are incorporated into a ribonucleoprotein complex (like siRNA). The differences between the siRNA and the miRNA are that miRNA is endogenous to every cell and it binds to its target, but - unlike siRNA - the complementary is not $100 \%$. Moreover, miRNA causes the translational inhibition of the target mRNA, while siRNA cleaves it [15].

A novel technology exploiting both the cleavage and the translational inhibition has been described. It is called bifunctional shRNA. The bi-functional concept is to design 
one bi-shRNA with two stem-loop shRNAs for each targeted mRNA - one stem-loop shRNA structure with a perfect match and one with mismatches at the central location. The "bi-functional" shRNA, by virtue of loading onto multiple types of RISCs - both cleavage-dependent RISC (fully matched shRNA) and cleavage-independent RISC (mismatched shRNA) - is able to simultaneously induce degradation of target mRNA and also inhibit translation through mRNA sequestration. Compared to siRNA or miRNA, it leads to a more rapid onset of gene silencing, greater durability and higher efficacy $[16,17]$.

The RNAi-based mechanism is involved in many physiological processes in a wide range of species. For example, in Caenorhabditis elegans and Drosophila melanogaster RNAi controls transposons [18, 19], in yeast RNA interference is involved in heterochromatin formation $[20,21]$, in plants it is used as a defense against viral infection [22]. Regardless of the function which RNAi plays in organisms, it can be used to alter gene expression. These small molecules may be used to shut down the activity of mutant genes, which contributes to the cure of many diseases.

The discovery of RNA interference made it possible to acquire another tool for gene therapy. The research conducted in this area offers the hope that RNAi molecules will be much more effective in gene therapy than molecules used so far, like chemically modified antisense oligonucleotides (AON) [23], or ribozymes [24]. Most comparative studies have already demonstrated that the effect of siRNA lasts longer than the effect after the administration with $\mathrm{AON}$ or ribozymes [10]. In contrast to drugs based on antisense nucleotides, siRNA molecules can cleave not only one individual mRNA. One molecule of siRNA causes the degradation of many molecules of the messenger RNA. Low concentration of siRNA, which is needed to elicit a positive effect and the fact that siRNA rapidly and specifically associates with RISC, reduce the binding of siRNA to other cellular proteins [25]. Introducing synthetic siRNAs in nanomolar concentrations can cause an effective downregulation in the expression of the target mRNA [26].

\section{POTENTIAL SIDE EFFECTS}

To be effective as a medicine, RNAi cannot cause any effects, except those which are associated with silencing of the target gene. This issue is particularly important in therapeutic applications where side effects are very undesirable. The sources of these adverse effects are non-specific silencing of genes, so called off-target silencing $[27,28]$ and the fact that siRNAs longer than 30bp trigger the interferon pathway [29]. This induction of secretion interferon is due to the innate immune system. Our organism, which recognizes long dsRNA as a virus particle, "thinks that something is wrong" and tries to overcome the infection [30]. To avoid this problem scientists need to use particles with a length of 21-23 bp [29]. Another problem is the fact that gene silencing by transfection the mammalian cells with siRNA is not stable and long lasting (like in Caenorhabditis elegans [31]) but is transient. To overcome this problem RNAi can be introduced into mammalian cells by vector systems in two types: shRNAs - hairpin type where sense and antisense strands are expressed by one polymerase III promoters [32] or by Tan- dem type where sense and antisense strands are expressed by two separate polymerase III promoters and the strands anneal inside the cells. In both cases the molecules are converted into siRNA by using cellular machinery - Dicer [33, 34]. According to Miyagishi [35] shRNA - type is a more potent silencer of gene expression. Nowadays actually not polymerase III but polymerase II is used to construct a gene expression system for in vivo and in vitro applications. It is due to the fact that polymerase III lacks control of spatial and temporal gene expression and can compete for and occupy endogenous nuclear export mechanism [36]. There are several ways to obtain siRNA, for example chemical synthesis [37], enzymatic cleavage [38], cloning of sequence coding antisense RNA into plasmid, transfection and expression in cells [39] or cloning into adenoviral [40], lentiviral [41] or retroviral vectors [42]. Transfection can be performed either by electroporation [43] or by lipid-based formulations [44].

\section{THE SPECTRUM OF THE USE OF RNAi IN VARI- OUS DISEASES}

RNA interference is used for the knockdown of gene expression in animals and promises to provide a quicker and cheaper way to generate knockout animals which are now an invaluable source of knowledge as models of disease [45]. RNAi was first used to treat hepatitis in the mouse liver [46]. A year later, the Food and Drug Administration approved the first clinical trials using RNA interference. There have been many studies in different systems in order to use RNAi to treat a bunch of different diseases. Currently the studies are related to the treatment of wet AMD (age-related macular degeneration), the major cause of blindness in the United States in patients over the age of 55. The goal of this therapies is inhibiting VEGF (Vascular Endothelial Growth Factor) [47]. After some setbacks - with AGN211745 (Ranibizumab) which did not pass Phase II trials - Cand5 is the siRNA currently in Phase II trials for use in AMD and also diabetic macular degeneration [48].

siRNA can be also used as a new antiviral therapy [49, 50]. In the case of HIV - CCR5 was silenced by transduction the cells with lentiviral vector with shRNA recognizing CCR5. This RNAi procedure had no side effects and resulted in the prevention of viral entry into human peripheral blood lymphocytes [51, 52]. Also in the case of hepatitis B, transfection of siRNA into HepG2.2.15 cells, which constitutively produce HBV particles, caused a significant reduction in viral RNA production [53]. Another therapeutic agent - PF05095808 - has an antiviral activity against chronic hepatitis C virus. PF-05095808 comprises a recombinant adenoassociated virus (AAV) DNA vector which directs expression of three shRNAs targeted to conserved regions of the HCV genome [54].

siRNA appears also to be ideal for inhibiting influenza virus infection [55]. The influenza virus is an RNA virus, without any DNA intermediates during its entire life cycle, and its genome encodes only 10 proteins. Each of these proteins plays a critical role during the virus life cycle. Interference with the production of any one of them is likely to have severe consequences on viral replication and production [56, 57]. Unfortunately, up to date scientists have not managed to create siRNA which eliminates the influenza problem. 
Probably the reason for this issue is viral escape. Viral replication can be blocked efficiently at the beginning, but after a while the virus titer increases again, because of the selection of mutants which can overcome the inhibition. The solution to this problem could be siRNA which targets strongly conserved regions of the virus.

siRNA can also be used as a tool to fight parasites. For example, silencing PP1 serine/threonine protein phosphatase by using RNAi could disrupt the life cycle of Plasmodium falciparum - the causative agent of malaria [58].

There are also attempts to use RNAi in diseases in which there is no viable pharmaceutical treatment option so that surgical intervention is the first-line treatment. An example of such a disease is a Familial Adenomatous Polyposis (FAP). In classical FAP $\beta$-catenin gene is known to be dysregulated. CEQ508 drug candidate (Marina Biotech) is a live attenuated Escherichia coli engineered to enter into dysplastic tissue and release a payload of shRNA to silence $\beta$-catenin expression. CEQ508 has been shown in the nonclinical setting to reduce the amount of intracellular $\beta$ catenin.

RNAi can also be used in inherited metabolic disorders like mucopolisaccharidoses (MPS). Mucopolysaccharidoses are caused by the absence or malfunctioning of lysosomal enzymes needed to break down molecules called glycosaminoglycans (gag). The buildup of undegraded heparan gag in the brain cells of affected MPS children results in a progressive neurological deterioration. One approach is substrate deprivation therapy (SDT), which acts by inhibiting the synthesis of the substrate for the missing enzyme [59]. Unfortunately chemical SDT agents tested reduce the synthesis of all gag type. The RNA interference technology is one way of specifically targeting the synthesis of an individual gag type by reducing the expression of one or more of the glycosyl transferases responsible for gag synthesis - only these gag types that are involved in a specific MPS disorder. One of such gag types is heparan sulphate. EXTL2 and EXTL3 are the enzymes involved in heparan sulphare synthesis. RNAi was used by Kaidonis et al. to specifically target EXTL2 and EXTL3 expression. All shRNAs directed at EXTL2 significantly decreased gag synthesis in an MPS cell lines [60]. In another study [61] the mRNA levels of genes XYLT1, XYLT2, GALTI and GALTII were reduced by the use of siRNA. The products of these genes are involved in gag synthesis. It showed the feasibility of using the RNAi approach in reducing the buildup of tissue gag characteristic of MPS disorders. What is interesting, Dziedzic et al. showed that using two siRNAs is generally more effective than using single siRNA, but the differences were not statistically significant. Therefore the potential benefit from the use of two siRNAs over the use of a single siRNA is doubtful in the light of the cost-benefit ratio and possibly stronger sideeffects of the putative therapy [62].

\section{RNAi AGAINST CANCER}

RNA interference due to its specificity and breadth of targeting capability could be used as a therapeutic weapon in a number of diseases. Cancers are not an exception. A large number of preclinical studies have presented favorable out- comes by silencing genes critical for tumor cell growth, metastasis, angiogenesis and chemoresistance.

Lung cancer is a worldwide leading cause of death [63]. Patients with non-small-cell-lung cancer (NSCLC) are generally non-responsive to initial chemotherapy and despite extensive research efforts in screening, diagnostics and therapeutics, prognosis for suffering patients is still poor and only $8-14 \%$ of them survive more than 5 years from the time of diagnosis [64]. Because the tumor invasion and metastasis are characteristic for the aggressive phenotype of human cancers [65], finding a blocking factor of these stages of tumor development could facilitate the design of anticancer drugs. When it comes to NSCLC, VEGF-C appears to be a factor involved in the crucial stages of development and progression of cancer [66]. It was found that using siRNA against VEGF-C suppresses tumor cell growth, invasion and migration in vitro. And using lentivirus encoded shRNA against VEGF-C suppresses tumor cell growth, angiogenesis and lymphangiogenesis in vivo [67]. Using such a RNAi downregulates the chemokine receptors CXCR4 and CCR7 [67] which are highly expressed in many kinds of tumors and may be involved in metastatic process $[68,69]$. Silencing of VEGF-C also trapped VEGFR-3 [67] which in cancer cells promotes motility and invasion both in vitro and in vivo [68]. These findings suggest that siRNA targeting of VEGF-C can be an effective therapeutic strategy for non-small-cell lung cancer [70].

Another target for RNAi in NSCLC could be Nrf2 [Nuclear factor (erythroid-derived 2)-like 2]. This transcription factor activates cytoprotective pathways against oxidative injury and apoptosis. It also has the ability to regulate the expression of electrophile and xenobiotic detoxification enzymes as well as efflux proteins [71]. The activity of Nrf2 is increased in NSCLC cells due to the mutations in Nrf2 inhibitor - Keap1 [72]. Loss of Keap1 activity leads to constitutive activation of Nrf2 in lung cancer cells, which upregulates the expression of antioxidants, electrophile and drug detoxification enzymes and leads to the protection of cancer cells [73]. shRNA targeting the 3' end of the Nrf2 transcript is able to lower the Nrf 2 protein level. It induces generation of reactive oxygen species (ROS), suppresses tumor growth and results in increased sensitivity to chemotherapeutic drugs which induces cell death [74]. The downregulation of multidrug resistance protein like ATP-binding cassette by shRNA targeting Nrf2 is especially important in cancers with chemoresistance, like NSCLC, and it was proven [74] that such RNAi increased drug accumulation and enhanced chemosensitivity in cancer cells.

Sensitizing cells to apoptosis can also be achieved by silencing the inhibitors of this process, like Apollon, which is a member of the inhibitors of apoptosis protein (IAP) family [75]. It is known that this protein is upregulated in brain tumor such as glioma [76] and in acute myeloid leukemia [77]. The effects of Apollon knockdown, accomplished through RNA interference, were also examined for breast cancer. Apollon-specific siRNA was able to downregulate the in vitro proliferative potential of breast cancer cells. This RNAi has also the ability to induce the apoptosis in the cells mentioned [78]. These data suggests the opportunity to conduct a survey in which the tumor with overexpression of Apollon 
will be selected and treated with siRNA against this IAP. In this type of treatment using RNAi could bring a powerful tool in the fight against cancer.

Another regulator of apoptosis is type VI intermediate filament protein - Nestin [79]. It was shown that Nestin plays an important role in the promotion of cell proliferation [80]. Moreover, this protein exhibits cytoprotective functions in neural stem cells wherein it prevents $\mathrm{Cdk} 5$-dependent apoptosis by the sequestering of $\mathrm{Cdk} 5 / \mathrm{p} 35$ complexes [81]. Increased Nestin expression has been reported in various tumor cells, for example pancreatic ductal adenocarcinoma (PDAC) [82]. The fact that scientists in recent years are more and more interested in angiogenesis is not surprising when we consider angiogenesis as an attractive target for cancer therapy. Recently, the correlation between Nestin, angiogenesis and PDAC has been established. It was shown that Nestin may be a useful marker of newly-formed blood vessels in tumor tissues. Reduced Nestin expression - using the siRNA - affects the growth and migration activities of vascular endothelial cells. The inhibition of tumor growth was also indicated in vivo after using RNAi (anti-angiogenic effects on mouse's tumor vessels were shown) [83].

The effectiveness of anti-angiogenic agents for cancer treatment has been reported, and Nestin is not the only therapeutic target that can be silenced using RNAi to obtain downregulation of formation of new blood vessels from preexisting vessels. The most critical pro-angiogenic factor is the vascular endothelial growth factor. Rho GTPases are small molecule members of the Ras superfamily of small GTPases which function as molecular switches in the cell. It was shown that Rac1 is an important regulator of VEGFmediated angiogenesis [84]. Moreover, silencing of Rac1 using siRNA inhibited VEGF-mediated tube formation both in vitro and in vivo [85]. Another reason why Rac1 could be a good therapeutic target for RNAi in cancers is the fact that Rac1 in cancer cells is overexpressed and its activity is increased [86]. Rac1 silencing using siRNA inhibits VEGFinduced migration, invasion and proliferation of HUVECs (Human Umbilical Vein Endothelial Cells). This proves that inhibition of Rac1 using RNA interference is an effective tool for inhibiting angiogenesis and tumor growth.

Oncogenes expressed at abnormally high levels are also attractive targets for RNAi-based therapies against cancers. In ovarian cancer cells the tyrosine kinase receptor EphA2 gene is overexpressed, which is associated with poor clinical outcome. EphA2 can function as an oncoprotein which can be an ideal therapeutic target because its downregulation reduces tumorigenicity in preclinical studies of breast and pancreatic cancer $[87,88]$. After the delivery of siRNAs up to $50 \%$ reduction of tumor size was observed. Moreover, when RNAi therapy was combined with paclitaxel, up to $90 \%$ reduction in tumor size was observed [89]. The clinical study on safety and the highest tolerable dose of siRNAEphA2-DOP was started in May 2012.

\section{RNAi IN CLINICS}

The use of siRNA is not limited only to the laboratories. The first clinical applications of RNAi were directed against AMD, Parkinson's disease and amyothrophic lateral sclerosis [90], and although some of the clinical trials of siRNA were suspended - for example studies on Ranibizumab [91] it is not difficult to find examples of RNAi which are currently in clinical trials (Tables $\mathbf{1}, \mathbf{2}$ ). Below we present some of them.

\section{NON-CANCER RNAi-BASED THERAPIES UNDER- GOING CLINICAL TRIALS TD101}

Pachyonychia congenital (PC) is an autosomal dominant skin disorder, which affects an estimated 550 patients worldwide. Pathogenic mutations in keratin K6a, K6b, K16 or K17 act via a dominant negative mechanism, leading to manifestations of the disease. Patients with PC suffer from painful plantar blistering and keratoderma that requires usage of ambulation devices. Current treatment is limited to mechanical removal of the thick calluses, non-specific topical keratolytics, and oral retinoids. None of this is satisfactory. TransDerm Company designed siRNA for treatment of Pachyonychia Congenita - TD101, which is also the first siRNA-based therapeutic for skin. TD101 targets a single nucleotide mutation - K6a. Because of this, it will only be effective against PC subjects harboring this specific mutation, but with little or no effect on wild-type expression [92]. There are currently only six known patients who carry this mutation in the International Pachyonychia Congenita Research Registry. Phase Ib clinical trial to test the safety and efficacy of TD101 was evaluated in a single patient (woman), who is the only adult in the US known to have the particular mutation (K6a N171K mutant) that the drug targets. Two children of this woman also suffer from PC. It was decided that the treatment of the adult patient will be completed prior to the recruitment of the minors. The patient received TD101 twice a week for 17 weeks. During this time the dosage of the drug was increased steadily. Randomly assigned solutions of TD101 or vehicle control were injected in symmetric plantar calluses on opposite feet. During the first 2 months of the trial, no dramatic differences (subjective or objective) between feet were noted by either the patient or physician. On approximately day 70 of the trial the patient's subjective evaluation of the injected callus began to indicate a marked difference in the right foot, but no change in the left foot. On day 98 of the trial the callus at the site of injection on the right foot began to fall away and revealed healthy skin. Subjective and objective changes in the right foot began returning toward baseline after the drug was discontinued and reached baseline $\sim 30-50$ days after the last dose. No adverse events occurred during the trial or in the 3-month washout period. Subjective patient assessment and physician clinical efficacy measures revealed regression of callus on the siRNA-treated, but not on the vehicle-treated foot. The degree of pain experienced by the patient at the time of injection is a significant concern. Future efforts must focus on improved delivery methods for TD101, such as pharmaceutical formulations for noninvasive topical delivery (like cream) $[93,94]$. According to the Mary Schwartz, director of the PC project (the non-profit organization funding the drug's clinical development), TD101 will be tested in additional PC patients in Ireland.

\section{TKM-Ebola1}

The Zaire species of Ebola virus (ZEBOV) is associated with periodic outbreaks of hemorrhagic fever in human 
Table 1. RNAi-Based Other Than Cancer Therapies Undergoing Clinical Trials

\begin{tabular}{|c|c|c|c|c|}
\hline $\begin{array}{l}\text { Name of the } \\
\text { Molecule }\end{array}$ & Disease & Stage & Features & $\begin{array}{l}\text { Government Identifier } \\
\text { [90] Or References }\end{array}$ \\
\hline TD101 & Pachyonychia Congenita & Phase I trial & $\begin{array}{l}\text { siRNA targeting a } \mathrm{K} 6 \mathrm{a}-\text { one of the keratins } \\
\text { mutated in } \mathrm{PC}\end{array}$ & NCT00716014 \\
\hline TKM-Ebola & Ebola infection & Phase I trial & $\begin{array}{l}\text { siRNA targeting viral RNA; delivered by } \\
\text { SNALP liposome }\end{array}$ & NCT01518881 \\
\hline RXI-109 & Dermal scarring & Phase I trial & $\begin{array}{l}\text { RNAi targeting connective tissue growth } \\
\text { factor (CTGF); delivered by intradermal } \\
\text { needle injection }\end{array}$ & NCT01640912 \\
\hline SYL040012 & Intraocular pressure and glaucoma & Phase II trial & $\begin{array}{l}\text { siRNA administered topically to treat ocular } \\
\text { hypertension associated with open-angle } \\
\text { glaucoma }\end{array}$ & NCT00990743 \\
\hline ALN-PCSO2 & Hypercholesterolemia & Phase I trial & $\begin{array}{l}\text { SNALP-formulated RNAi targeting PCSK9 } \\
\text { what results in lower LDL cholesterol level }\end{array}$ & NCT01437059 \\
\hline ALN-RSV01 & RSV infection & Phase II trial & $\begin{array}{l}\text { siRNA targeting respiratory syncytial virus } \\
\text { replication }\end{array}$ & NCT01065935 \\
\hline ALN-TTR02 & TTR - mediated Amyloidosis & Phase II trial & siRNA targeting transthyretin & NCT01617967 \\
\hline $\begin{array}{l}\text { Bevasiranib } \\
\text { (Cand5) }\end{array}$ & $\begin{array}{l}\text { Wet Age-Related Macular Degen- } \\
\text { eration }\end{array}$ & Phase II trial & $\begin{array}{l}\text { siRNA silencing VEGF; the target population } \\
\text { are patients with diabetic macular edema }\end{array}$ & NCT00306904 \\
\hline
\end{tabular}

Table 2. RNAi-Based Cancer Therapies Undergoing Clinical Trials

\begin{tabular}{|c|c|c|c|c|}
\hline $\begin{array}{l}\text { Name of the Mole- } \\
\text { cule }\end{array}$ & Disease & Stage & Features & $\begin{array}{l}\text { Government Identifier } \\
\text { [90] Or Reference }\end{array}$ \\
\hline CALAA-01 & $\begin{array}{l}\text { Nonresectable or metastatic solid } \\
\text { tumors }\end{array}$ & Phase I trial & $\begin{array}{l}\text { siRNA against M2 subunit of ribonucleotide } \\
\text { reductase in nanoparticles; causes antiprolif- } \\
\text { erative effects }\end{array}$ & NCT00689065 [91] \\
\hline Atu027 & Solid tumors & Phase I trial & $\begin{array}{l}\text { siRNA targeting Protein Kinase N3 gene ex- } \\
\text { pression in the vascular endothelium }\end{array}$ & NCT00938574 [92] \\
\hline ALN-VSP02 & $\begin{array}{l}\text { Liver cancer, cancer with liver } \\
\text { involvement }\end{array}$ & Phase I trial & $\begin{array}{l}\text { SNALP formulation; dual-targeted RNAi } \\
\text { drug: anti-angiogenic mechanism (anti VEGF), } \\
\text { anti-proliferative mechnism (anti KSP) }\end{array}$ & NCT00882180 \\
\hline siRNA-EphA2-DOP & Advanced Cancers & Phase I trial & $\begin{array}{l}\text { siRNA targeting EphA2 gene using neutral } \\
\text { liposomal delivery }\end{array}$ & NCT01591356 \\
\hline TKM-PLK1 & $\begin{array}{l}\text { Primary or Secondary Liver Can- } \\
\text { cer }\end{array}$ & Phase I trial & $\begin{array}{l}\text { Lipid nanoparticles containing siRNA against } \\
\text { the PLK1 gene product }\end{array}$ & NCT01262235 \\
\hline SPC2996 & $\begin{array}{l}\text { Chronic lymphocytic leukemia } \\
\text { (CLL) }\end{array}$ & Phase II trial & $\begin{array}{l}\text { Antisense molecule targeting the mRNA of the } \\
\text { Bcl-2 oncoprotein; causes immunostimulatory } \\
\text { effects }\end{array}$ & NCT00285103 [93] \\
\hline FANG $^{\mathrm{TM}}$ Vaccine & Advanced Solid Tumors & Phase I trial & $\begin{array}{l}\text { Plasmid encoding GMCSF and bi-shRNA } \\
\text { designed to indirectly reduce levels of TGF } \beta \\
\text { isoforms by targeting furin convertase }\end{array}$ & NCT01061840 [94] \\
\hline FANG $^{\mathrm{TM}}$ Vaccine & $\begin{array}{l}\text { High Risk Stage IIIc Ovarian } \\
\text { Cancer }\end{array}$ & Phase II trial & $\begin{array}{l}\text { Plasmid encoding GMCSF and bi-shRNA } \\
\text { designed to indirectly reduce levels of TGF } \beta \\
\text { isoforms by targeting furin convertase }\end{array}$ & NCT01309230 \\
\hline FANG $^{\mathrm{TM}}$ Vaccine & Advanced Melanoma & Phase II trial & $\begin{array}{l}\text { Plasmid encoding GMCSF and bi-shRNA } \\
\text { designed to indirectly reduce levels of TGF } \beta \\
\text { isoforms by targeting furin convertase }\end{array}$ & NCT01453361 \\
\hline
\end{tabular}


(Table 2) contd....

\begin{tabular}{|l|l|l|l|l|}
\hline $\begin{array}{l}\text { Name of the Mole- } \\
\text { cule }\end{array}$ & Disease & Stage & Features & $\begin{array}{l}\text { Government Identifier } \\
\text { [90] Or Reference }\end{array}$ \\
\hline \hline FANG ${ }^{\text {TM }}$ Vaccine & Colorectal Cancer & Phase II trial & $\begin{array}{l}\text { Plasmid encoding GMCSF and bi-shRNA } \\
\text { designed to indirectly reduce levels of TGF } \\
\text { isoforms by targeting furin convertase }\end{array}$ & NCT01505166 \\
\hline siG12D LODER & $\begin{array}{l}\text { Unresectable Locally Advanced } \\
\text { Pancreatic Cancer }\end{array}$ & $\begin{array}{l}\text { Miniature biodegradable polymeric matrix } \\
\text { containing siRNA for the mutated KRAS } \\
\text { oncogene }\end{array}$ & NCT01676259 \\
\hline
\end{tabular}

populations with mortality rates reaching $90 \%$. The first outbreak occurred on 26 August 1976 in Yambuku. Unfortunately, there is currently no FDA-approved ebolavirusspecific therapy for Ebola virus disease [95]. Ebola virus genome contains, among others, the L protein-coding genes and VP35 which make up the polymerase complex. The polymerase complex is responsible for the transcription and replication process of the Ebola virus genome. The $\mathrm{L}$ protein seems to be an ideal target for antiviral interventions. Its suppression should lead to a nearly complete loss of all RNA synthesis. Moreover, there are no similar proteins in mammalian cells [96].

In February 2012 TKM-Ebola Phase I clinical trial was initiated. This RNAi therapeutic was invented by Tekmira Pharmaceuticals Corporation. TKM-Ebola is delivered using Tekmira's lipid nanoparticle (LNP) delivery technology. LNP platform is being utilized in multiple clinical trials by both Tekmira and its partners. In this technology siRNA is encapsulated with high efficiency in uniform lipid nanoparticles that are effective in delivering RNAi therapeutics to disease sites in numerous preclinical models. LNP-based products have been reviewed by multiple FDA divisions for use in clinical trials.

The objective of the Phase I trial is to assess the safety and tolerability of TKM-Ebola and evaluate the pharmacokinetics and systemic exposure following both a singleascending dose and multiple-ascending doses of TKMEbola. During this trial specific FDA regulatory guidelines called the "Animal Rule" will be used. "Animal rule" is a path to drug approval for life-threatening agents where human efficacy trials aren't ethical or feasible [97].

\section{RXI-109}

Dermal wound healing is a complex process that, when properly orchestrated, leads to re-establishment of skin integrity with minimal residual scarring. Hypertrophic scars, which are an outcome of burns or surgery, represent an example of pathologic dermal scarring. They can be characterized by a diverse spectrum of disorders like unsightly scars, keloids or even life-threatening systemic diseases such as scleroderma. Over-expression of connective tissue growth factor (CTGF) mRNA and protein has been observed in chronic fibrotic disorders affecting multiple organ systems. Although CTGF has minimal basal expression in the normal skin, it demonstrates transient up-regulation for several days following dermal injury. Persistent over-expression of CTGF has been observed in biopsies of keloids and localized scle- rosis. Therefore CTGF, as a one of the key regulator of scarring, may be an attractive target for scar prevention [98].

RXI-109 was designed by RXi Pharmaceuticals to reduce or prevent skin scarring following trauma or surgery and is intended to reduce disfiguring hypertrophic scarring and keloids. This RNAi compound has been shown to effectively silence CTGF in vitro in cell culture and in vivo in rodent skin models. In July 2012 Phase I clinical trial on RXI-109 was initiated. The primary purpose of that study is to evaluate the safety and tolerability of a single intradermal administration of RXI-109 at small surgical incisions in the abdominal skin that will later be removed during an elective abdominoplasty. The effect of RXI-109 versus placebo on scarring at these incision sites will be evaluated visually and histologically [99]. In September 2012 RXi Pharmaceuticals Corporation announced that RXI-109 was well tolerated by intradermal injection. No serious local or systemic side effects were observed in the subjects at any of the doses administered. Local erythema (redness) around the injection site was somewhat more pronounced in the cohort that received the highest dose, but these instances of redness disappeared usually within 72 hours after the injection, and did not give rise to significant subjective complaints from the study subjects [100].

\section{SYL040012}

Glaucoma is a group of progressive optic neuropathies. Without adequate treatment, glaucoma can progress to irreversible visual disability and eventual blindness [101]. Of the many types of glaucoma, primary open angle glaucoma (POAG) is perhaps the most common. In most cases of POAG, increased resistance to the outflow of aqueous humor results in a rise in intraocular pressure (IOP), which eventually leads to loss of retinal ganglion cells. New siRNA invented in Sylentis biopharmaceutical company - SYL040012 has proven to be effective in vivo when administered topically to treat ocular hypertension associated with open-angle glaucoma. These trials showed that pretreatment with SYL040012 prevents the induced increase in intraocular pressure in this ocular hypertension model. The prophylactic effect of this compound is greater than the one described previously in this model with the drugs currently used for treating glaucoma, such as timolol or Xalatan. The results of the Phase I trial were presented at the 7 th Conference of the Spanish Society for Glaucoma, in Alicante. The Phase I trial endpoint was to determine the tolerance and safety of SYL040012 ophthalmic drops. It was administered to 30 
healthy volunteers aged 18 to 33 . Patients showed excellent local and systemic tolerance to SYL040012, leading to very positive trial results. On 13 June 2012 Sylentis has received authorization from the Spanish and Estonian regulatory agencies to commence Phase II clinical trials with SYL040012 for treating ocular hypertension associated with glaucoma. The endpoint of this trial is to evaluate the effect of a range of doses of the drug on 80 patients with ocular hypertension or glaucoma in the three countries [102].

\section{ALN-PCS02}

Coronary artery disease is the leading cause of death in the U.S. Most forms of hypercholesterolemia can be treated through statins. However, there are patient populations that are statin intolerant or statin resistant. After 2003 proprotein convertase subtilisn/kexin type 9 (PCSK9), which is one of the serine proteases, has emerged as a novel target to lower low-density lipoprotein (LDL) cholesterol levels. PCSK9 binds to hepatic LDL receptors and targets them for degradation. This process reduces the capacity of the liver to bind and remove LDL cholesterol and results in increased LDL cholesterol levels. Some patients with low levels of LDL cholesterol had PCSK9 loss-of-function mutations and these patients had a reduced incidence of coronary heart disease. These studies raised the possibility that inhibition of PCSK9 or its mRNA might lower LDL cholesterol levels in patients with hypercholesterolemia [103]. Alnylam Pharmaceuticals develops ALN-PCS02 - a RNAi therapeutic for the treatment of hypercholesterolemia, or high levels of cholesterol in the blood. This RNAi therapeutic targets the gene PCSK9 and has the potential to lower tissue and circulating PCSK9 levels resulting in higher LDL receptor levels in the liver, and subsequently lower LDL cholesterol levels.

Pre-clinical data with ALN-PCS02 have shown specific silencing of PCSK9 mRNA and PCSK9 serum protein levels of up to $90 \%$. These studies have also demonstrated a greater than $50 \%$ reduction in the levels of LDL, which is rapid and durable, lasting for weeks after a single dose. Positive results from the Phase I trial were presented in April 2012. These results showed that ALN-PCS02, in the absence of concomitant lipid-lowering agents such as statins, resulted in statistically significant and durable reductions of PCSK9 plasma levels of up to $84 \%$ and lowering of LDL up to $50 \%$. ALNPCS02 was shown to be safe and well tolerated. Moreover, there were no serious adverse events related to study drug administration [104].

\section{ALN-RSV01}

Human respiratory syncytial virus (RSV) is a ubiquitous virus and the most common cause of serious lower respiratory tract infections in infants and young children worldwide, as well as an important pathogen in elderly individuals and immunocompromised patients [105]. Despite nearly four decades of research, no RSV vaccine approach has been successful at conferring protection at a level that exceeds the incomplete protection afforded by natural infection. Currently, the only antiviral approved for use for the treatment of RSV infection is ribavirin, but due to its teratogenicity, limited efficacy, and poorly understood mechanism of action, it has very limited use [106]. The N, P, and L proteins are contained within the nucleocapsid of the virion and are required for various steps within the replication cycle. Consistent with their absence from the outer virus surface, the RNAs encoding the $\mathrm{N}, \mathrm{P}$, and L proteins are among the most highly conserved regions of the RSV genome. Therefore, screening of siRNAs targeting the mRNAs for this proteins would result in the selection of the most potent and broadspectrum inhibitors of viral replication [107]. Alnylam Pharmaceuticals RNAi therapeutic - ALN-RSV01 - was designed to target the nucleocapsid $\mathrm{N}$ gene of the RSV genome because, as mentioned, this nucleocapsid gene is critical to viral replication. ALN-RSV01 has shown a robust antiviral effect in vitro against RSV [108].

In Phase I trial ALN-RSV01 has been shown to be safe and well tolerated [109]. In Phase II trial in experimentally infected adults, intranasal ALN-RSV01 reduced the rate of RSV infection by 44\% [104, 110, 111]. In September 2012 complete results from Phase IIb trial were reported. It was shown that treatment with ALN-RSV01 gave an over eightfold reduced risk in developing progressive bronchiolitis obliterans syndrome (BOS) at 180 days after RSV infection. Alnylam Pharmaceuticals plans to meet with U.S. and European regulatory authorities to determine next steps for this program [104, 112].

\section{ALN-TTR02}

RNAi gives hope also for patients with orphan diseases. Transthyretin-mediated amyloidosis (ATTR) is one of such diseases. ATTR is caused by mutations in the transthyretin (TTR) gene, which is expressed predominantly in the liver. This mutation results in the accumulation of toxic deposits of the misfolded protein in several tissues including nerves, heart, and gastrointestinal tract. Liver transplantation is the only treatment option for ATTR, but this invasive procedure is not available for most ATTR patients, whose life expectancy is from five to fifteen years from the onset of the disease. The Alnylam Pharmaceuticals designed ALN-TTR02 a siRNA which specifically inhibits TTR mRNA, thereby reducing the accumulation of TTR protein. In July 2012 Alnylam Pharmaceuticals announced the achievement of positive clinical results from Phase I trial with ALN-TTR02: up to $94 \%$ reduction of serum TTR and a nearly $80 \%$ level of suppression sustained at one month with just a single dose. In June 2012 Phase II study of ALN-TTR02 (evaluating clinical activity, safety, and tolerability) was initiated in ATTR patients [104].

\section{Bevasiranib (Cand5)}

Diabetic macular edema (DME) is the leading cause of vision loss in diabetic retinopathy. DME is the result of the breakdown of the retinal capillary endothelium in patients with diabetes mellitus (Type I and II) and the critical molecule involved in the pathogenesis of neovascular eye diseases - like DME - is VEGF. The majority of antiangiogenic agents with evidence of clinical efficacy at this time generally act by inhibiting VEGF. Anti-VEGF therapies have been shown to be remarkably effective in preventing vision loss from the neovascular and exudative complications of retinal diseases. Bevasiranib (Acuity Pharmaceuticals) is a siRNA molecule which targets the messenger RNA of the VEGF 
protein. This RNAi therapeutical, known previously as Cand5, after intravitreal injection is well distributed within the eye and localizes to the retina $[113,114]$. Cand5 showed in Phase I clinical studies to be safe and well tolerated in patients with DME. The purpose of Phase II study is to evaluate the pharmacokinetics, safety and preliminary efficacy of 3 doses of Cand5.

\section{RNAi-BASED CANCER THERAPIES UNDERGOING CLINICAL TRIALS}

RNA interference due to its specificity and adaptability has great potential to serve as a personalized gene therapy against cancer. The use of RNAi may lead to downregulation of metastasis, angiogenesis and chemoresistance as well as upregulation the apoptosis. These features indicate that the use of RNAi could cause antitumor effects. siRNA could be, for example, a hope for patients with brain tumors. The most devastating primary human brain tumor is Glioblastoma multiforme $(\mathrm{GBM})$. The current therapy for GBM is based on surgery followed by radiotherapy and chemotherapy [115]. Unfortunately, mediana patients survival is approximately only 8 months. Glioma cell invasion mechanism is based on the attachment of tumor cells to extracellular matrix, its degradation and penetration into adjacent brain structures [116]. RNAi against tenascin-C (extracellular matrix protein, highly expressed in cancer tissues and probably responsible for invasiveness of glioma cells [117]) was injected into the postoperative area of the patient's brain.

Positive effects of RNAi applications in patients with a brain tumor on survivals compared to the bronchytherapy was characterized by The Karnofsky Performance Scale Index (KPS). KPS allows the description of the patients functional impairment. This index can be used to compare effectiveness of different therapies and to assess the prognosis in individual patients [118]. Because the most malignant gliomas are known to be chemo- and radiotherapy resistant due to the inhibition of the apoptotic pathway, recently discovered RNA interference phenomenon may be the method of choice suitable for such treatment [89].

Below we present other anti-cancer molecules which use the RNA interference mechanism and are under clinical trials.

\section{CALAA-01}

Ribonucleotide reductase (RR) catalyzes the conversion of ribonucleoside 5 -diphosphates into their corresponding 2 -deoxyribonucleotides and is a rate-limiting step in the pathway for the production of 2 -deoxyribonucleoside 5triphosphates that are necessary for DNA replication. Human RR consists of two subunits, RRM1 and RRM2, and the expression of both proteins is required for enzymatic activity [119]. RR has long been an important target for controlling pathologies that depend on DNA replication. Moreover, inhibition of RR activity has been tested as potential anticancer therapy.

siRNA against RRM2 has antiproliferative activity in many cancer types [120]. Whang et al. have used siRNA against RRM2 to enhance pancreatic adenocarcinoma chemosensitivity to gemcitabine and retrovirally expressed
siRNA against RRM2 to attenuate pancreatic adenocarcinoma cellular invasiveness and diminish its gemcitabine resistance [121]. These reports provide motivation for study of siRNA-mediated inhibition of RRM2 because potent sequences could provide for specific and effective therapies.

The delivery of siRNA into the human body is problematic for a long time. Particles which are designed to act in living organisms have to be no-antigenic which will allow repeat dosing. Nucleic acid should be encapsulated to protect its structure from nucleases and Toll-like receptors on cell surface. Particle size should be larger than $10 \mathrm{~nm}$ but not larger than $75 \pm 25 \mathrm{~nm}$ (to minimize renal clearance) [122] Because of these, as well as many other restrictions, until 2008 there was no particle in clinics which was able to deliver siRNA for cancer. In 2008 Calando Pharmaceuticals was the first to enter the clinic with their target delivery of siRNA for cancers - CALAA-01 [123]. The exact nature of CALAA-01 has not been reported, but it is known that this nanoparticle consists of cyclodextrin-containing polymer (CDP), an adamantane -PEG conjugate (AD-PEG) and adamantane conjugate of PEG that has human transferrin (Tf) conjugated at the end opposite to the adamantane (Tf-PEGAD) combined with siRNA against RRM2. The transferrin on the nanoparticle is able to bind to transferrin receptors (TfRs) which are a cell surface protein overexpressed on various cancer cell types. The nanoparticles can be internalized via receptor-mediated endocytosis. As mentioned previously, siRNA against RRM2 has antiproliferative activity in many cancer types [120]. The CALAA-01 siRNA is protected from nuclease degradation within a stabilized nanoparticle targeted to tumor cells. CALAA-01 is now in the Phase I trial. According to the service of the U.S. National Institutes of Health [124] this Phase will:

- Determine the safety, toxicity, and the maximum tolerated dose (MTD) of CALAA-01 when administered intravenously to patients with relapsed or refractory cancer.

- Characterize the pharmacokinetics (PK) of CALAA-01 after intravenous administration.

- $\quad$ Provide preliminary evidence of efficacy of intravenous CALAA-01 by evaluating tumor response.

- Recommend a dose of intravenous CALAA-01 for future clinical studies.

- Evaluate immune response, by measuring antibody and cytokine levels, and the effect of intravenous CALAA01 on complement.

The estimated study completion date was December 2012, but unfortunately no study results had been published before this review was completed.

\section{Atu027}

Another interesting agent against cancer was designed by Silence Therapeutics - one of the leading companies dealing with the use of RNA interference for the therapeutic purposes. The name of the molecule, which is a lipoplex containing siRNA, is Atu027 [125]. It was designed to silence gene expression of protein kinase N3 (PKN3) in the vascular endothelium during the therapy of solid tumors. 
PKN3 is involved in signal transduction in the PI3K pathway which regulates a diverse set of cellular responses including growth, development, survival, motility, adhesion, immune cell function and glucose transport. PI3K is only transiently activated after growth factor stimulation of normal cells, and is rapidly turned off through tumor suppressor PTEN function. Excessive, chronic activation of this pathway is observed in many types of cancer and appears to be involved in the process of metastasis [126]. A number of kinases and other signaling molecules, which mediate PI3Kregulated events, represent candidate cancer therapy targets. However, most of these proteins act rather upstream in the PI3K signaling cascade and regulate multiple functions in normal cells. Because of this - their inhibition is likely to cause side effects. Leenders et al. identified and validated PKN3, a barely characterized protein kinase C-related molecule, as a novel effector mediating malignant cell growth downstream of activated PI3K [127]. Preclinical studies demonstrated that Atu027, which targets PKN3 gene expression in vascular endothelium, is able to significantly inhibit the PKN3 pathway, tumor growth and metastasis. Recently, PKN3 has also been considered as a suitable therapeutic target for modulating tumor-associated angiogenesis, because analysis with Atu027 in cultured primary endothelial cells revealed an essential role of PKN3 for endothelial tube formation and migration [125]. Moreover, tests with Atu027 showed no interferon response or activation of cytokines, which is a frequent problem occurring when siRNA is administered. Probably, closing the siRNA in lipoplex ensured the high safety of this drug [128].

In the completed Phase I, the aim of which was to find the correct dose, it was shown that Atu027 is well tolerated and so far no dose dependent toxicities have been observed. Plasma samples of the patients showed dose-dependent increase in siRNA antisense strand concentrations [128]. Therefore undoubtedly, Atu027 is a novel, promising investigational therapeutic agent in anticancer therapy.

\section{ALN-VSP02}

VEGF and kinesin spindle protein (KSP) are upregulated in many tumor cells and play an important role in tumor proliferation and survival. Because we have mentioned VEGF before, here we will only mention KSP. This motor protein has an exclusive and essential role in mitosis. It is required early in mitosis to separate the centrosomes of the emerging spindle poles, thus driving establishment of a bipolar mitotic spindle.

Failure to establish a bipolar spindle results in a mitotic arrest, after which cells may experience a variety of fates, including abnormal exit from mitosis, resumption of the cell cycle, and apoptosis [129]. Inhibition of KSP results in mitotic arrest characterized by an abnormal mitotic spindle. The essential role of KSP in cell cycle makes it a target of intense research for the development of novel anticancer therapeutics.

ALN-VSP02 is a first dual-targeted RNAi drug - contains two siRNA: anti mRNA for KSP (anti-proliferative) and anti mRNA for VEGF (anti-angiogenic mechanism). Preventing translation of mRNA for these proteins may result in inhibition of tumor cells growth. In ALN-VSP02 therapeutic a
SNALP (solid nucleic acid lipid particle) formulation was used. The Phase I clinical trial using ALN-VSP02 against hepatocellular carcinoma, which is the most common cancer worldwide, has been completed. Results were presented in June 2012. These data included safety and tolerability of multiple doses of ALN-VSP02, as well as evidence for antitumor activity in this very advanced, heavily pre-treated cancer patient population. It showed that multiple patients achieved stable disease or better, including a patient with endometrial cancer metastatic to the liver who achieved a complete response [104].

\section{SiRNA-EphA2-DOPC}

Processes like metastasis, proliferation and angiogenesis are crucial to malignant progression. Receptor tyrosine kinase (EphA2) was shown to be very important in those processes. EphA2 is expressed at low levels in adult epithelial cells and can negatively regulate cellular growth and migration. However, over-expression of this receptor is present in many human cancers, and it may be involved in controlling the proliferation, metastasis, and apoptosis of tumor cells. There are studies showing that a high level of EphA2 is often associated with poor prognostic features [130-133]. Downregulation of the receptor has been shown to decrease tumor growth and prolong survival in multiple preclinical models of ovarian, breast and pancreatic cancers. In ovarian cancer EphA2 is over-expressed in more than $75 \%$ of cases. Moreover, EphA2 seems to be an attractive target because of its low expression in normal adult tissue. In siRNA-EphA2DOPC siRNA is incorporated in the neutral liposome - 1,2dioleoyl-sn-glycero-3-phosphatidylcholine (DOPC) what allows intra-tumor delivery. The clinical study started in May 2012 [134]. The goal of this clinical research is to learn about the safety of siRNA-EphA2-DOPC when given to patients with advanced, recurrent cancer. Researchers also want to learn the highest tolerable dose of this drug that can be given. The estimated primary completion date is March 2018 [124].

\section{TKM-PLK1}

PLK1 is a cell cycle-regulated kinase whose expression peaks during $\mathrm{G}_{2} \mathrm{M}$ Phase of the cell cycle and transiently associates with the spindle apparatus and the centromere region of mitotic chromosomes. It controls entry into mitosis and regulates the spindle checkpoint. It is often deregulated and overexpressed in tumor cells. RNAi-mediated depletion of PLK1 mRNA can lead to cell cycle arrest, growth inhibition and apoptosis in cancer cells. It is known that the nanoparticles carrying siRNA targeting the Plk1 gene can induce remarkable apoptosis in both HepG2 and MDA-MB435 s cancer cells. Systemic delivery of specific siRNA by nanoparticles significantly inhibited luciferase expression in an orthotopic murine liver cancer model and suppressed tumor growth in a MDA-MB-435s murine xenograft model, suggesting its therapeutic promise in disease treatment [135]. In June 2012 a new drug, TKM-PLK1, was introduced to the clinical study. The study is designed to determine the safety, tolerability of TKM-PLK1 in adult patients with solid tumors or lymphomas that are refractory to standard therapy or for whom there is no standard therapy. The drug was given directly into the cancer blood supply in the liver circulation. It 
contains siRNA against Plk1 gene and there is evidence that it should cause tumors to shrink, which would help people to live longer or would made tumors easy to remove by surgery [136].

\section{SPC2996}

In cancer the apoptosis cell-division ratio is altered. Bcl-2 is an apoptosis suppressor protein, which has the ability to extend the lifespan of the cell. It is known that the expression of Bcl-2 in malignant tumors is higher than in normal cells [137, 138]. SPC2996 is a novel antisense molecule against chronic lymphocytic leukemia (CLL), which is the most common leukemia in adults in Western Europe and North America [139]. The drug binds with high potency to the messenger RNA for Bcl-2 and destroys it, resulting in a reduction in Bcl-2 protein concentration. The Phase II study for this drug was completed. The purpose of this study was to determine whether SPC2996 is effective and safe in the treatment of CLL. No study results had been published before this review was completed [124].

\section{FANG $^{\text {TM }}$}

Often in cancer therapy RNAi molecules are combined with other agents. In FANG ${ }^{\mathrm{TM}}$ Vaccine bifunctional short hairpin RNAi (bi-shRNA) was combined with granulocytemacrophage colony-stimulating factor (GMCSF). The GMCSF protein is a potent stimulator of the immune system, recruiting and activating antigen presenting cells at the site of intradermal injection thereby promoting antigen presentation. bi-shRNA was developed to exploit both the cleavage and translational inhibition mechanisms of RNAi. Such molecules are able to induce RNase-H like cleavage and non-cleavage mediated degradation of the target mRNA. The furin bifunctional shRNA blocks furin protein production at the post transcriptional and translational levels. This decreases the conversion of the proforms TGF $\beta 1$ and TGF $\beta 2$ proteins. Also, reduced furin protein levels have a negative feedback inhibition on TGF $\beta 1$ and TGF $\beta 2$ gene expressions, decreasing the levels of their mRNAs. The resulting decrease in TGF $\beta 1$ and TGF $\beta 2$ proteins reduces the local immunosuppression they cause and promotes tumor surface antigen and MHC protein display. Such interference downregulates endogenous TGF $\beta 1$ which reduces the cytokine-associated immune suppression that is well documented in cancer patients. Using bi-shRNA - instead of siRNA or miRNA - increases the efficacy of gene silencing [140]. There are four FANG vaccine related clinical trials:

1. A Phase I Trial of FANG ${ }^{\mathrm{TM}}$ Vaccine for advanced solid tumors. This safety study is currently recruiting participants. Estimated study completion date is December 2014.

2. A Phase II Trial of FANG ${ }^{\mathrm{TM}}$ Vaccine for high risk stage IIIc ovarian cancer. This safety and efficacy study is currently recruiting participants. Trial endpoints include time to recurrence documentation of immune responses, correlation of immune response and clinical effect. Estimated study completion date is January 2016.
3. A Phase II Trial of FANG ${ }^{\mathrm{TM}}$ Vaccine for patients with advanced melanoma. This is a safety and efficacy study of intradermal autologous FANG cancer vaccine in patients with stages IIIc and IV melanoma with biopsy accessible lesions to document blood and intratumoral immune responses and assess correlation with survival. This study is currently recruiting participants. Estimated study completion date is December 2013. The investigators have completed the Phase I assessment of FANG vaccine. The study was done in 27 advanced solid tumor patients group. None of these patients have experienced significant adverse effects following 131 vaccinations, including 4 patients with melanoma. Plasmid functionality, immune biomarker response, and preliminary evidence of anticancer activity have been observed.

4. A Phase II Trial of FANG ${ }^{\mathrm{TM}}$ Vaccine for patients with colorectal cancer. This efficacy study is currently recruiting participants. Estimated study completion date is January 2015. The investigators have completed the Phase I assessment of FANG vaccine in 30 advanced solid tumor patients who have not experienced any significant adverse effects following 144 vaccinations, including 6 patients with colorectal carcinoma.

\section{SiG12D LODER}

KRAS is a member of the small GTPase superfamily. In over $90 \%$ of human pancreatic ductal adenocarcinomas this protein is mutated. This mutation can be associated with tumor cell proliferation and reduced survival. siG12D LODER contains siRNA for the siG12D (mutated KRAS oncogen). In this drug the biodegradable polymer matrix was used. This matrix allows local deliver of siRNA into the pancreatic tumor not at once, but over a sustained period of about 8 weeks [141]. siG12D LODER has been studied in the escalating dose Phase I study of 12 patients, and the results showed a high safety and tolerability profile. In Phase II study a single dose $3,000 \mu \mathrm{g}$ will be administered to patients with unresectable locally advanced pancreatic cancer (LAPC) combined with chemotherapy treatment (Gemcitabine or FOLFIRINOX). This will be the first study to assess the response rate of the siG12D LODER in patients with unresectable LAPC.

\section{CONCLUSIONS}

The discovery of RNAi has brought many changes to modern physiology and medicine. It opened up new possibilities for the study of proteins and genes functions in different organisms. But probably the most important fact is that this discovery puts a new weapon in the hands of specialists in the fight against diseases with such different surfaces like AMD, RSV, HIV, hepatitis C or Huntington disease, and, as demonstrated in the studies cited, also in the fight against various types of cancers.

\section{CONFLICT OF INTEREST}

The author(s) confirm that this article content has no conflict of interest. 


\section{ACKNOWLEDGEMENTS}

Declared none.

\section{ABBREVIATIONS}

\begin{tabular}{|c|c|c|}
\hline AAV & $=$ & Adeno-Associated Virus \\
\hline AD-PEG & $=$ & An Adamantane -PEG Conjugate \\
\hline AMD & $=$ & Age-Related Macular Degeneration \\
\hline AON & $=$ & Antisense Oligonucleotides \\
\hline ATTR & $=$ & Transthyretin-Mediated Amyloidosis \\
\hline bi-shRNA & $=$ & Bifunctional Short Hairpin RNAi \\
\hline BOS & $=$ & Bronchiolitis Obliterans Syndrome \\
\hline $\mathrm{CDP}$ & $=$ & Cyclodextrin-Containing Polymer \\
\hline CLL & $=$ & Chronic Lymphocytic Leukemia \\
\hline CTGF & $=$ & Connective Tissue Growth Factor \\
\hline DME & $=$ & Diabetic Macular Edema \\
\hline DOPC & $=$ & $\begin{array}{l}\text { 1,2-dioleoyl-sn-glycero-3-Phosphatidyl } \\
\text { choline }\end{array}$ \\
\hline dsRNA & $=$ & Double-Stranded RNA \\
\hline FAP & $=$ & Familial Adenomatous Polyposis \\
\hline Gag & $=$ & Glycosaminoglycans \\
\hline GBM & $=$ & Glioblastoma Multiforme \\
\hline GMCSF & $=$ & $\begin{array}{l}\text { Granulocyte-Macrophage Colony-Stimula } \\
\text { ting Factor }\end{array}$ \\
\hline HIF-1 & $=$ & Hypoxia-Induced Factor \\
\hline HUVECs & $=$ & Human Umbilical Vein Endothelial Cells \\
\hline IAP & $=$ & Inhibitors of Apoptosis Protein \\
\hline IOP & $=$ & Intraocular Pressure \\
\hline KSP & $=$ & Kinesin Spindle Protein \\
\hline LAPC & $=$ & Locally Advanced Pancreatic Cancer \\
\hline LNP & $=$ & Lipid Nanoparticle \\
\hline MPS & $=$ & Mucopolisaccharidoses \\
\hline NSCLC & $=$ & Non-Small-Cell-Lung Cancer \\
\hline Nrf2 & $=$ & Nuclear Factor (erythroid-derived 2)-like 2 \\
\hline $\mathrm{PC}$ & $=$ & Pachyonychia Congenital \\
\hline PCSK9 & $=$ & $\begin{array}{l}\text { The Gene Proprotein Convertase Sub- } \\
\text { tilisn/kexin Type } 9\end{array}$ \\
\hline PDAC & $=$ & Pancreatic Ductal Adenocarcinoma \\
\hline PKN3 & $=$ & Protein Kinase N3 \\
\hline POAG & $=$ & Primary Open Angle Glaucoma \\
\hline PTGS & $=$ & Post-Transcriptional Gene Silencing \\
\hline RISC & $=$ & RNA-Induced Silencing Complex \\
\hline RNAi & $=$ & RNA Interference \\
\hline ROS & $=$ & Reactive Oxygen Species \\
\hline
\end{tabular}

\begin{tabular}{|c|c|c|}
\hline $\mathrm{RR}$ & $=$ & Ribonucleotide Reductase \\
\hline RRM2 & $=$ & Ribonucleotide Reductase Subunit \\
\hline RSV & $=$ & Respiratory Syncytial Virus \\
\hline SDT & $=$ & Substrate Deprivation Therapy \\
\hline shRNA & $=$ & Short Hairpin RNA \\
\hline siRNA & $=$ & Small Interfering RNA \\
\hline SNALP & $=$ & Solid Nucleic Acid Lipid Particles \\
\hline Tf-PEG-AD & $=$ & $\begin{array}{l}\text { Adamantane Conjugate of PEG that has } \\
\text { Human Transferrin (Tf) Conjugated At the } \\
\text { End Opposite to the Adamantane }\end{array}$ \\
\hline TTR & $=$ & Transthyretin \\
\hline VEGF & $=$ & Vascular Endothelial Growth Factor \\
\hline ZEBOV & $=$ & Zaire Species of Ebola Virus \\
\hline
\end{tabular}

\section{REFERENCES}

[1] Wang, Z.; Rao, D. D.; Senzer, N.; Nemunaitis, J. RNA Interference and Cancer Therapy. Pharm. Res., 2011, 28 (12), 2983-2995.

[2] Fire, A.; Xu, S.; Montgomery, M. K.; Kostas, S. A.; Driver, S. E.; Mello, C. C. Potent and specific genetic interference by doublestranded RNA in Caenorhabditis elegans. Nature, 1998, 391 (6669), 806-811.

[3] Hammond, S. M.; Caudy, A. A.; Hannon, G. J. Post-transcriptional gene silencing by double-stranded RNA. Nat. Rev. Genet., 2001, 2 (2), 110-119.

[4] Zamore, P. D.; Tuschl, T.; Sharp, P. A.; Bartel, D. P. RNAi: double-stranded RNA directs the ATP-dependent cleavage of mRNA at 21 to 23 nucleotide intervals. Cell, 2000, 101 (1), 25-33.

[5] Ambros, V.; Bartel, B.; Bartel, D. P.; Burge, C. B.; Carrington, J. C.; Chen, X.; Dreyfuss, G.; Eddy, S. R.; Griffiths-Jones, S.; Marshall, M.; Matzke, M.; Ruvkun, G.; Tuschl, T. A uniform system for microRNA annotation. RNA, 2003, 9 (3), 277-279.

[6] Rychahou, P. G.; Jackson, L. N.; Farrow, B. J.; Evers, B. M. RNA interference: mechanisms of action and therapeutic consideration. Surgery, 2006, 140 (5), 719-725.

[7] Klase, Z.; Winograd, R.; Davis, J.; Carpio, L.; Hildreth, R.; Heydarian, M.; Fu, S.; McCaffrey, T.; Meiri, E.; Ayash-Rashkovsky, M.; Gilad, S.; Bentwich, Z.; Kashanchi, F. HIV-1 TAR miRNA protects against apoptosis by altering cellular gene expression. Retrovirology., 2009, 6,18 .

[8] Klase, Z.; Kale, P.; Winograd, R.; Gupta, M. V.; Heydarian, M.; Berro, R.; McCaffrey, T.; Kashanchi, F. HIV-1 TAR element is processed by Dicer to yield a viral micro-RNA involved in chromatin remodeling of the viral LTR. BMC. Mol. Biol., 2007, 8, 63 .

[9] Bernstein, E.; Caudy, A. A.; Hammond, S. M.; Hannon, G. J. Role for a bidentate ribonuclease in the initiation step of RNA interference. Nature, 2001, 409 (6818), 363-366.

[10] Kisielow, M.; Kleiner, S.; Nagasawa, M.; Faisal, A.; Nagamine, Y. Isoform-specific knockdown and expression of adaptor protein ShcA using small interfering RNA. Biochem. J., 2002, 363 (Pt 1), $1-5$.

[11] Caudy, A. A.; Ketting, R. F.; Hammond, S. M.; Denli, A. M.; Bathoorn, A. M.; Tops, B. B.; Silva, J. M.; Myers, M. M.; Hannon, G. J.; Plasterk, R. H. A micrococcal nuclease homologue in RNAi effector complexes. Nature, 2003, 425 (6956), 411-414.

[12] Robb, G. B.; Brown, K. M.; Khurana, J.; Rana, T. M. Specific and potent RNAi in the nucleus of human cells. Nat. Struct. Mol. Biol. 2005, 12 (2), 133-137.

[13] Mittal, V. Improving the efficiency of RNA interference in mammals. Nat. Rev. Genet., 2004, 5 (5), 355-365.

[14] Lee, Y.; Ahn, C.; Han, J.; Choi, H.; Kim, J.; Yim, J.; Lee, J.; Provost, P.; Radmark, O.; Kim, S.; Kim, V. N. The nuclear RNase III Drosha initiates microRNA processing. Nature, 2003, 425 (6956), 415-419.

[15] Zeng, Y.; Yi, R.; Cullen, B. R. MicroRNAs and small interfering RNAs can inhibit mRNA expression by similar mechanisms. Proc. Natl. Acad. Sci. U. S. A, 2003, 100 (17), 9779-9784. 
[16] Rao, D. D.; Vorhies, J. S.; Senzer, N.; Nemunaitis, J. siRNA vs. shRNA: similarities and differences. Adv. Drug Deliv. Rev., 2009, 61 (9), 746-759.

[17] Rao, D. D.; Senzer, N.; Wang, Z.; Kumar, P.; Jay, C. M.; Nemunaitis, J. Bifunctional short hairpin RNA (bi-shRNA): design and pathway to clinical application. Methods Mol. Biol., 2013, 942, 259-278.

[18] Abrusan, G.; Krambeck, H. J. Competition may determine the diversity of transposable elements. Theor. Popul. Biol., 2006, 70 (3), 364-375.

[19] Ghildiyal, M.; Seitz, H.; Horwich, M. D.; Li, C.; Du, T.; Lee, S.; Xu, J.; Kittler, E. L.; Zapp, M. L.; Weng, Z.; Zamore, P. D. Endogenous siRNAs derived from transposons and mRNAs in Drosophila somatic cells. Science, 2008, 320 (5879), 1077-1081.

[20] Reyes-Turcu, F. E.; Grewal, S. I. Different means, same endheterochromatin formation by RNAi and RNAi-independent RNA processing factors in fission yeast. Curr. Opin. Genet. Dev., 2012.

[21] Zofall, M.; Yamanaka, S.; Reyes-Turcu, F. E.; Zhang, K.; Rubin, C.; Grewal, S. I. RNA elimination machinery targeting meiotic mRNAs promotes facultative heterochromatin formation. Science, 2012, 335 (6064), 96-100.

[22] Voinnet, O. RNA silencing as a plant immune system against viruses. Trends Genet., 2001, 17 (8), 449-459.

[23] Stein, C. A.; Krieg, A. M. Problems in interpretation of data derived from in vitro and in vivo use of antisense oligodeoxynucleotides. Antisense Res. Dev., 1994, 4 (2), 67-69.

[24] Pieken, W. A.; Olsen, D. B.; Aurup, H.; Williams, D. M.; Heidenreich, O.; Benseler, F.; Eckstein, F. Structure-function relationship of hammerhead ribozymes as probed by 2'-modifications. Nucleic Acids Symp. Ser., 1991, (24), 51-53.

[25] Love, K. T.; Mahon, K. P.; Levins, C. G.; Whitehead, K. A.; Querbes, W.; Dorkin, J. R.; Qin, J.; Cantley, W.; Qin, L. L.; Racie, T.; Frank-Kamenetsky, M.; Yip, K. N.; Alvarez, R.; Sah, D. W.; de, F. A.; Fitzgerald, K.; Koteliansky, V.; Akinc, A.; Langer, R.; Anderson, D. G. Lipid-like materials for low-dose, in vivo gene silencing. Proc. Natl. Acad. Sci. U. S. A, 2010, 107 (5), 1864-1869.

[26] Shang, X.; Wang, Y.; Zhao, Q.; Wu, K.; Li, X.; Ji, X.; He, R.; Zhang, W. siRNAs target sites selection of ezrin and the influence of RNA interference on ezrin expression and biological characters of osteosarcoma cells. Mol. Cell Biochem., 2012.

[27] Jackson, A. L.; Burchard, J.; Schelter, J.; Chau, B. N.; Cleary, M.; Lim, L.; Linsley, P. S. Widespread siRNA "off-target" transcript silencing mediated by seed region sequence complementarity. RNA., 2006, 12 (7), 1179-1187.

[28] Qiu, S.; Adema, C. M.; Lane, T. A computational study of offtarget effects of RNA interference. Nucleic Acids Res., 2005, 33 (6), 1834-1847.

[29] Hornung, V.; Guenthner-Biller, M.; Bourquin, C.; Ablasser, A.; Schlee, M.; Uematsu, S.; Noronha, A.; Manoharan, M.; Akira, S.; de, F. A.; Endres, S.; Hartmann, G. Sequence-specific potent induction of IFN-alpha by short interfering RNA in plasmacytoid dendritic cells through TLR7. Nat. Med., 2005, 11 (3), 263-270.

[30] Goodchild, A.; Nopper, N.; King, A.; Doan, T.; Tanudji, M.; Arndt, G. M.; Poidinger, M.; Rivory, L. P.; Passioura, T. Sequence determinants of innate immune activation by short interfering RNAs. BMC. Immunol., 2009, 10, 40.

[31] Grishok, A.; Mello, C. C. RNAi (Nematodes: Caenorhabditis elegans). Adv. Genet., 2002, 46, 339-360.

[32] Lee, N. S.; Dohjima, T.; Bauer, G.; Li, H.; Li, M. J.; Ehsani, A.; Salvaterra, P.; Rossi, J. Expression of small interfering RNAs targeted against HIV-1 rev transcripts in human cells. Nat. Biotechnol., 2002, 20 (5), 500-505.

[33] Tuschl, T. Expanding small RNA interference. Nat. Biotechnol., 2002, 20 (5), 446-448.

[34] Leung, R. K.; Whittaker, P. A. RNA interference: from gene silencing to gene-specific therapeutics. Pharmacol. Ther., 2005, 107 (2), 222-239

[35] Miyagishi, M.; Taira, K. Strategies for generation of an siRNA expression library directed against the human genome. Oligonucleotides., 2003, 13 (5), 325-333.

[36] Wang, Z.; Rao, D. D.; Senzer, N.; Nemunaitis, J. RNA interference and cancer therapy. Pharm. Res., 2011, 28 (12), 2983-2995.

[37] Elbashir, S. M.; Harborth, J.; Lendeckel, W.; Yalcin, A.; Weber, K.; Tuschl, T. Duplexes of 21-nucleotide RNAs mediate RNA interference in cultured mammalian cells. Nature, 2001, 411 (6836), 494-498.
[38]

Kittler, R.; Putz, G.; Pelletier, L.; Poser, I.; Heninger, A. K.; Drechsel, D.; Fischer, S.; Konstantinova, I.; Habermann, B.; Grabner, H.; Yaspo, M. L.; Himmelbauer, H.; Korn, B.; Neugebauer, K.; Pisabarro, M. T.; Buchholz, F. An endoribonuclease-prepared siRNA screen in human cells identifies genes essential for cell division. Nature, 2004, 432 (7020), 1036-1040.

[39] Zheng, L.; Liu, J.; Batalov, S.; Zhou, D.; Orth, A.; Ding, S.; Schultz, P. G. An approach to genomewide screens of expressed small interfering RNAs in mammalian cells. Proc. Natl. Acad. Sci. U. S. A, 2004, 101 (1), 135-140.

[40] Arts, G. J.; Langemeijer, E.; Tissingh, R.; Ma, L.; Pavliska, H. Dokic, K.; Dooijes, R.; Mesic, E.; Clasen, R.; Michiels, F.; van der Schueren, J.; Lambrecht, M.; Herman, S.; Brys, R.; Thys, K.; Hoffmann, M.; Tomme, P.; van, E. H. Adenoviral vectors expressing siRNAs for discovery and validation of gene function. Genome Res., 2003, 13 (10), 2325-2332.

[41] Rubinson, D. A.; Dillon, C. P.; Kwiatkowski, A. V.; Sievers, C.; Yang, L.; Kopinja, J.; Rooney, D. L.; Zhang, M.; Ihrig, M. M.; McManus, M. T.; Gertler, F. B.; Scott, M. L.; Van, P. L. A lentivirus-based system to functionally silence genes in primary mammalian cells, stem cells and transgenic mice by RNA interference. Nat. Genet., 2003, 33 (3), 401-406.

[42] Brummelkamp, T. R.; Bernards, R.; Agami, R. Stable suppression of tumorigenicity by virus-mediated RNA interference. Cancer Cell, 2002, 2 (3), 243-247.

[43] Gresch, O.; Engel, F. B.; Nesic, D.; Tran, T. T.; England, H. M.; Hickman, E. S.; Korner, I.; Gan, L.; Chen, S.; Castro-Obregon, S. Hammermann, R.; Wolf, J.; Muller-Hartmann, H.; Nix, M.; Siebenkotten, G.; Kraus, G.; Lun, K. New non-viral method for gene transfer into primary cells. Methods, 2004, 33 (2), 151-163.

[44] Brazas, R. M.; Hagstrom, J. E. Delivery of small interfering RNA to mammalian cells in culture by using cationic lipid/polymerbased transfection reagents. Methods Enzymol., 2005, 392, 112124.

[45] Kunath, T.; Gish, G.; Lickert, H.; Jones, N.; Pawson, T.; Rossant, J. Transgenic RNA interference in ES cell-derived embryos recapitulates a genetic null phenotype. Nat. Biotechnol., 2003, 21 (5), 559561.

[46] Chen, C. C.; Chang, C. M.; Sun, C. P.; Yu, C. P.; Wu, P. Y.; Jeng, K. S.; Hu, C. P.; Chen, P. J.; Wu, J. C.; Shih, C. H.; Gershwin, M. E.; Tao, M. H. Use of RNA interference to modulate liver adenoma development in a murine model transgenic for hepatitis B virus. Gene Ther., 2012, 19 (1), 25-33.

[47] Mousa, S. A.; Mousa, S. S. Current status of vascular endothelial growth factor inhibition in age-related macular degeneration. BioDrugs., 2010, 24 (3), 183-194.

[48] Haussecker, D. The business of RNAi therapeutics. Hum. Gene Ther., 2008, 19 (5), 451-462.

[49] McCaffrey, A. P.; Meuse, L.; Pham, T. T.; Conklin, D. S.; Hannon, G. J.; Kay, M. A. RNA interference in adult mice. Nature, 2002, 418 (6893), 38-39.

[50] Bitko, V.; Musiyenko, A.; Shulyayeva, O.; Barik, S. Inhibition of respiratory viruses by nasally administered siRNA. Nat. Med., 2005, 11 (1), 50-55.

[51] Shimizu, S.; Kamata, M.; Kittipongdaja, P.; Chen, K. N.; Kim, S Pang, S.; Boyer, J.; Qin, F. X.; An, D. S.; Chen, I. S. Characterization of a potent non-cytotoxic shRNA directed to the HIV-1 coreceptor CCR5. Genet. Vaccines. Ther., 2009, 7, 8.

[52] Qin, X. F.; An, D. S.; Chen, I. S.; Baltimore, D. Inhibiting HIV-1 infection in human $\mathrm{T}$ cells by lentiviral-mediated delivery of small interfering RNA against CCR5. Proc. Natl. Acad. Sci. U. S. A, 2003, 100 (1), 183-188.

[53] Giladi, H.; Ketzinel-Gilad, M.; Rivkin, L.; Felig, Y.; Nussbaum, O.; Galun, E. Small interfering RNA inhibits hepatitis B virus replication in mice. Mol. Ther., 2003, 8 (5), 769-776.

[54] Lavender, H.; Brady, K.; Burden, F.; Delpuech-Adams, O.; Denise, H.; Palmer, A.; Perkins, H.; Savic, B.; Scott, S.; Smith-Burchnell, C.; Troke, P.; Wright, J. F.; Suhy, D.; Corbau, R. In Vitro Characterization of the Activity of PF-05095808, a Novel Biological Agent for Hepatitis C Virus Therapy. Antimicrob. Agents Chemother., 2012, 56 (3), 1364-1375.

[55] ElHefnawi, M.; Hassan, N.; Kamar, M.; Siam, R.; Remoli, A. L.; El-Azab, I.; AlAidy, O.; Marsili, G.; Sgarbanti, M. The design of optimal therapeutic small interfering RNA molecules targeting diverse strains of influenza A virus. Bioinformatics., 2011, 27 (24) $3364-3370$ 
[56] Ge, Q.; Eisen, H. N.; Chen, J. Use of siRNAs to prevent and treat influenza virus infection. Virus Res., 2004, 102 (1), 37-42.

[57] Kumar, P.; Sood, V.; Vyas, R.; Gupta, N.; Banerjea, A. C.; Khanna, M. Potent inhibition of influenza virus replication with novel siRNA-chimeric-ribozyme constructs. Antiviral Res., 2010, 87 (2), 204-212.

[58] Kumar, R.; Adams, B.; Oldenburg, A.; Musiyenko, A.; Barik, S. Characterisation and expression of a PP1 serine/threonine protein phosphatase (PfPP1) from the malaria parasite, Plasmodium falciparum: demonstration of its essential role using RNA interference. Malar. J., 2002, 1,5 .

[59] Inokuchi, J.; Radin, N. S. Preparation of the active isomer of 1phenyl-2-decanoylamino-3-morpholino-1-propanol, inhibitor of murine glucocerebroside synthetase. J. Lipid Res., 1987, 28 (5), $565-571$

[60] Kaidonis, X.; Liaw, W. C.; Roberts, A. D.; Ly, M.; Anson, D.; Byers, S. Gene silencing of EXTL2 and EXTL3 as a substrate deprivation therapy for heparan sulphate storing mucopolysaccharidoses. Eur. J. Hum. Genet., 2010, 18 (2),, 194-199.

[61] Dziedzic, D.; Wegrzyn, G.; Jakobkiewicz-Banecka, J. Impairment of glycosaminoglycan synthesis in mucopolysaccharidosis type IIIA cells by using siRNA: a potential therapeutic approach for Sanfilippo disease. Eur. J. Hum. Genet., 2010, 18 (2),, 200-205.

[62] Dziedzic, D.; Narajczyk, M.; Gabig-Ciminska, M.; JakobkiewiczBanecka, J. Simultaneous siRNA-mediated silencing of pairs of genes coding for enzymes involved in glycosaminoglycan synthesis. Acta Biochim. Pol., 2012, 59 (2), 293-298.

[63] Carr, L. L.; Finigan, J. H.; Kern, J. A. Evaluation and treatment of patients with non-small cell lung cancer. Med. Clin. North Am., 2011, 95 (6), 1041-1054.

[64] Howard, B. A.; Furumai, R.; Campa, M. J.; Rabbani, Z. N.; Vujaskovic, Z.; Wang, X. F.; Patz, E. F., Jr. Stable RNA interferencemediated suppression of cyclophilin A diminishes non-small-cell lung tumor growth in vivo. Cancer Res., 2005, 65 (19), 8853-8860.

[65] Steeg, P. S. Metastasis suppressors alter the signal transduction of cancer cells. Nat. Rev. Cancer, 2003, 3 (1), 55-63.

[66] Li, M.; Chen, H.; Diao, L.; Zhang, Y.; Xia, C.; Yang, F. Caveolin-1 and VEGF-C promote lymph node metastasis in the absence of intratumoral lymphangiogenesis in non-small cell lung cancer. $\mathrm{Tu}$ mori, 2010, 96 (5), 734-743.

[67] Feng, Y.; Hu, J.; Ma, J.; Feng, K.; Zhang, X.; Yang, S.; Wang, W.; Zhang, J.; Zhang, Y. RNAi-mediated silencing of VEGF-C inhibits non-small cell lung cancer progression by simultaneously downregulating the CXCR4, CCR7, VEGFR-2 and VEGFR-3-dependent axes-induced ERK, p38 and AKT signalling pathways. Eur. J. Cancer, 2011, 47 (15), 2353-2363.

[68] Muller, A.; Homey, B.; Soto, H.; Ge, N.; Catron, D.; Buchanan, M. E.; McClanahan, T.; Murphy, E.; Yuan, W.; Wagner, S. N.; Barrera, J. L.; Mohar, A.; Verastegui, E.; Zlotnik, A. Involvement of chemokine receptors in breast cancer metastasis. Nature, 2001, 410 (6824), 50-56.

[69] Takanami, I. Overexpression of CCR7 mRNA in nonsmall cell lung cancer: correlation with lymph node metastasis. Int. J. Cancer, 2003, 105 (2), 186-189.

[70] Timoshenko, A. V.; Rastogi, S.; Lala, P. K. Migration-promoting role of VEGF-C and VEGF-C binding receptors in human breast cancer cells. Br. J. Cancer, 2007, 97 (8), 1090-1098.

[71] Kensler, T. W.; Wakabayashi, N.; Biswal, S. Cell survival responses to environmental stresses via the Keap1-Nrf2-ARE pathway. Annu. Rev. Pharmacol. Toxicol., 2007, 47, 89-116.

[72] Singh, A.; Misra, V.; Thimmulappa, R. K.; Lee, H.; Ames, S.; Hoque, M. O.; Herman, J. G.; Baylin, S. B.; Sidransky, D.; Gabrielson, E.; Brock, M. V.; Biswal, S. Dysfunctional KEAP1-NRF2 interaction in non-small-cell lung cancer. PLoS. Med., 2006, 3 (10), e420.

[73] Padmanabhan, B.; Tong, K. I.; Ohta, T.; Nakamura, Y.; Scharlock, M.; Ohtsuji, M.; Kang, M. I.; Kobayashi, A.; Yokoyama, S.; Yamamoto, M. Structural basis for defects of Keap1 activity provoked by its point mutations in lung cancer. Mol. Cell, 2006, 21 (5), 689700.

[74] Singh, A.; Boldin-Adamsky, S.; Thimmulappa, R. K.; Rath, S. K.; Ashush, H.; Coulter, J.; Blackford, A.; Goodman, S. N.; Bunz, F.; Watson, W. H.; Gabrielson, E.; Feinstein, E.; Biswal, S. RNAimediated silencing of nuclear factor erythroid-2-related factor 2 gene expression in non-small cell lung cancer inhibits tumor growth and increases efficacy of chemotherapy. Cancer Res., 2008, 68 (19), 7975-7984.

[75] Srinivasula, S. M.; Ashwell, J. D. IAPs: what's in a name? Mol. Cell, 2008, 30 (2), 123-135.

[76] Chen, Z.; Naito, M.; Hori, S.; Mashima, T.; Yamori, T.; Tsuruo, T. A human IAP-family gene, apollon, expressed in human brain cancer cells. Biochem. Biophys. Res. Commun., 1999, 264 (3), 847854.

[77] Sung, K. W.; Choi, J.; Hwang, Y. K.; Lee, S. J.; Kim, H. J.; Lee, S. H.; Yoo, K. H.; Jung, H. L.; Koo, H. H. Overexpression of Apollon, an antiapoptotic protein, is associated with poor prognosis in childhood de novo acute myeloid leukemia. Clin. Cancer Res., 2007, 13 (17), 5109-5114.

[78] Lopergolo, A.; Pennati, M.; Gandellini, P.; Orlotti, N. I.; Poma, P.; Daidone, M. G.; Folini, M.; Zaffaroni, N. Apollon gene silencing induces apoptosis in breast cancer cells through p53 stabilisation and caspase-3 activation. Br. J. Cancer, 2009, 100 (5), 739-746.

[79] Huang, Y. L.; Wu, C. M.; Shi, G. Y.; Wu, G. C.; Lee, H.; Jiang, M. J.; Wu, H. L.; Yang, H. Y. Nestin serves as a prosurvival determinant that is linked to the cytoprotective effect of epidermal growth factor in rat vascular smooth muscle cells. J. Biochem., 2009, 146 (3), 307-315.

[80] Daniel, C.; Albrecht, H.; Ludke, A.; Hugo, C. Nestin expression in repopulating mesangial cells promotes their proliferation. Lab Invest, 2008, 88 (4), 387-397.

[81] Sahlgren, C. M.; Pallari, H. M.; He, T.; Chou, Y. H.; Goldman, R. D.; Eriksson, J. E. A nestin scaffold links Cdk5/p35 signaling to oxidant-induced cell death. EMBO J., 2006, 25 (20), 4808-4819.

[82] Kawamoto, M.; Ishiwata, T.; Cho, K.; Uchida, E.; Korc, M.; Naito, Z.; Tajiri, T. Nestin expression correlates with nerve and retroperitoneal tissue invasion in pancreatic cancer. Hum. Pathol., 2009, 40 (2), 189-198.

[83] Yamahatsu, K.; Matsuda, Y.; Ishiwata, T.; Uchida, E.; Naito, Z. Nestin as a novel therapeutic target for pancreatic cancer via tumor angiogenesis. Int. J. Oncol., 2012. 40 (5), 1345-1357.

[84] Fryer, B. H.; Field, J. Rho, Rac, Pak and angiogenesis: old roles and newly identified responsibilities in endothelial cells. Cancer Lett., 2005, 229 (1), 13-23.

[85] Vader, P.; van der Meel, R.; Symons, M. H.; Fens, M. H.; Pieters, E.; Wilschut, K. J.; Storm, G.; Jarzabek, M.; Gallagher, W. M.; Schiffelers, R. M.; Byrne, A. T. Examining the role of Rac1 in tumor angiogenesis and growth: a clinically relevant RNAi-mediated approach. Angiogenesis., 2011, 14 (4), 457-466.

[86] Aznar, S.; Fernandez-Valeron, P.; Espina, C.; Lacal, J. C. Rho GTPases: potential candidates for anticancer therapy. Cancer Lett., 2004, 206 (2), 181-191.

[87] Duxbury, M. S.; Ito, H.; Zinner, M. J.; Ashley, S. W.; Whang, E. E. EphA2: a determinant of malignant cellular behavior and a potential therapeutic target in pancreatic adenocarcinoma. Oncogene, 2004, 23 (7), 1448-1456.

[88] Gilabert-Estelles, J.; Braza-Boils, A.; Ramon, L. A.; Zorio, E.; Medina, P.; Espana, F.; Estelles, A. Role of microRNAs in gynecological pathology. Curr. Med. Chem., 2012, 19 (15), 2406-2413.

[89] Kim, D. H.; Rossi, J. J. Strategies for silencing human disease using RNA interference. Nat. Rev. Genet., 2007, 8 (3), 173-184.

[90] Wolters, N. M.; MacKeigan, J. P. From sequence to function: using RNAi to elucidate mechanisms of human disease. Cell Death. Differ., 2008, 15 (5), 809-819.

[91] Kleinman, M. E.; Yamada, K.; Takeda, A.; Chandrasekaran, V. Nozaki, M.; Baffi, J. Z.; Albuquerque, R. J.; Yamasaki, S.; Itaya, M.; Pan, Y.; Appukuttan, B.; Gibbs, D.; Yang, Z.; Kariko, K.; Ambati, B. K.; Wilgus, T. A.; DiPietro, L. A.; Sakurai, E.; Zhang, K.; Smith, J. R.; Taylor, E. W.; Ambati, J. Sequence- and targetindependent angiogenesis suppression by siRNA via TLR3. $\mathrm{Na}$ ture, 2008, 452 (7187), 591-597.

[92] Hickerson, R. P.; Flores, M. A.; Leake, D.; Lara, M. F.; Contag, C. H.; Leachman, S. A.; Kaspar, R. L. Use of self-delivery siRNAs to inhibit gene expression in an organotypic pachyonychia congenita model. J. Invest Dermatol., 2011, 131 (5), 1037-1044.

[93] Hickerson, R. P.; Leachman, S. A.; Pho, L. N.; Gonzalez-Gonzalez, E.; Smith, F. J.; McLean, W. H.; Contag, C. H.; Leake, D.; Milstone, L. M.; Kaspar, R. L. Development of quantitative molecular clinical end points for siRNA clinical trials. J. Invest Dermatol., 2011, 131 (5), 1029-1036.

[94] Leachman, S. A.; Hickerson, R. P.; Schwartz, M. E.; Bullough, E. E.; Hutcherson, S. L.; Boucher, K. M.; Hansen, C. D.; Eliason, M. 
J.; Srivatsa, G. S.; Kornbrust, D. J.; Smith, F. J.; McLean, W. I.; Milstone, L. M.; Kaspar, R. L. First-in-human mutation-targeted siRNA Phase Ib trial of an inherited skin disorder. Mol. Ther., 2010, 18 (2), 442-446.

[95] Nkoghe, D.; Formenty, P.; Nnegue, S.; Mve, M. T.; Hypolite, I.; Leonard, P.; Leroy, E. [Practical guidelines for the management of Ebola infected patients in the field]. Med. Trop. (Mars. ), 2004, 64 (2), 199-204.

[96] Geisbert, T. W.; Lee, A. C.; Robbins, M.; Geisbert, J. B.; Honko, A. N.; Sood, V.; Johnson, J. C.; de, J. S.; Tavakoli, I.; Judge, A.; Hensley, L. E.; Maclachlan, I. Postexposure protection of nonhuman primates against a lethal Ebola virus challenge with RNA interference: a proof-of-concept study. Lancet, 2010, 375 (9729), 1896-1905.

[97] Raven, K. Stop-work order creates uncertainty for Ebola drug research. Nat. Med., 2012, 18 (9), 1312.

[98] Sisco, M.; Kryger, Z. B.; O'Shaughnessy, K. D.; Kim, P. S.; Schultz, G. S.; Ding, X. Z.; Roy, N. K.; Dean, N. M.; Mustoe, T. A. Antisense inhibition of connective tissue growth factor (CTGF/CCN2) mRNA limits hypertrophic scarring without affecting wound healing in vivo. Wound. Repair Regen., 2008, 16 (5), 661-673.

[99] RXi Pharmaceuticals Corporation. http://www.rxipharma.com/rxi109/ (Accessed January 5, 2013)

[100] Medical News http://www.news-medical.net/news/20120924/RXicompletes-dosing-in-RXI-109-Phase-1-study-for-dermalscarring.aspx (Accessed January 05,, 2013)

[101] Li, M.; Xu, J.; Chen, X.; Sun, X. RNA interference as a gene silencing therapy for mutant MYOC protein in primary open angle glaucoma. Diagn. Pathol., 2009, 4, 46.

[102] Sylentis Company http://www.sylentis.com/index.php/en/news/51zeltia-informa-que-su-filial-sylentis-ha-recibido-autorizacionpara.html (Accessed January 5, 2013).

[103] Stein, E. A.; Mellis, S.; Yancopoulos, G. D.; Stahl, N.; Logan, D.; Smith, W. B.; Lisbon, E.; Gutierrez, M.; Webb, C.; Wu, R.; Du, Y.; Kranz, T.; Gasparino, E.; Swergold, G. D. Effect of a monoclonal antibody to PCSK9 on LDL cholesterol. N. Engl. J. Med., 2012, 366 (12), 1108-1118.

[104] Alnylam Clinical and Development Programs http://www.alnylam.com/Programs-and-Pipeline/index.php (Accessed January 5, 2013).

[105] Billings, J. L.; Hertz, M. I.; Wendt, C. H. Community respiratory virus infections following lung transplantation. Transpl. Infect. Dis., 2001, 3 (3), 138-148.

[106] Ventre, K.; Randolph, A. G. Ribavirin for respiratory syncytial virus infection of the lower respiratory tract in infants and young children. Cochrane. Database. Syst. Rev., 2007, (1), CD000181.

[107] Sullender, W. M. Respiratory syncytial virus genetic and antigenic diversity. Clin. Microbiol. Rev., 2000, 13 (1), 1-15, table.

[108] Alvarez, R.; Elbashir, S.; Borland, T.; Toudjarska, I.; Hadwiger, P.; John, M.; Roehl, I.; Morskaya, S. S.; Martinello, R.; Kahn, J.; Van, R. M.; Tripp, R. A.; DeVincenzo, J. P.; Pandey, R.; Maier, M.; Nechev, L.; Manoharan, M.; Kotelianski, V.; Meyers, R. RNA interference-mediated silencing of the respiratory syncytial virus nucleocapsid defines a potent antiviral strategy. Antimicrob. Agents Chemother., 2009, 53 (9), 3952-3962.

[109] DeVincenzo, J.; Cehelsky, J. E.; Alvarez, R.; Elbashir, S.; Harborth, J.; Toudjarska, I.; Nechev, L.; Murugaiah, V.; Van, V. A.; Vaishnaw, A. K.; Meyers, R. Evaluation of the safety, tolerability and pharmacokinetics of ALN-RSV01, a novel RNAi antiviral therapeutic directed against respiratory syncytial virus (RSV). Antiviral Res., 2008, 77 (3), 225-231.

[110] Zamora, M. R.; Budev, M.; Rolfe, M.; Gottlieb, J.; Humar, A.; Devincenzo, J.; Vaishnaw, A.; Cehelsky, J.; Albert, G.; Nochur, S.; Gollob, J. A.; Glanville, A. R. RNA interference therapy in lung transplant patients infected with respiratory syncytial virus. Am. J. Respir. Crit Care Med., 2011, 183 (4), 531-538.

[111] Burnett, J. C.; Rossi, J. J.; Tiemann, K. Current progress of siRNA/shRNA therapeutics in clinical trials. Biotechnol. J., 2011, 6 (9), 1130-1146.

[112] DeVincenzo, J.; Lambkin-Williams, R.; Wilkinson, T.; Cehelsky, J.; Nochur, S.; Walsh, E.; Meyers, R.; Gollob, J.; Vaishnaw, A. A randomized, double-blind, placebo-controlled study of an RNAibased therapy directed against respiratory syncytial virus. Proc. Natl. Acad. Sci. U. S. A, 2010, 107 (19), 8800-8805.
[113] Ni, Z.; Hui, P. Emerging pharmacologic therapies for wet agerelated macular degeneration. Ophthalmologica, 2009, 223 (6), 401-410.

[114] Tolentino, M. J.; Brucker, A. J.; Fosnot, J.; Ying, G. S.; Wu, I. H.; Malik, G.; Wan, S.; Reich, S. J. Intravitreal injection of vascular endothelial growth factor small interfering RNA inhibits growth and leakage in a nonhuman primate, laser-induced model of choroidal neovascularization. Retina, 2004, 24 (1), 132-138.[105a]

[115] Sathornsumetee, S.; Rich, J. N. New treatment strategies for malignant gliomas. Expert. Rev. Anticancer Ther., 2006, 6 (7), 1087 1104.

[116] Miller, C. R.; Perry, A. Glioblastoma. Arch. Pathol. Lab Med., 2007, 131 (3), 397-406.

[117] Zukiel, R.; Nowak, S.; Wyszko, E.; Rolle, K.; Gawronska, I.; Barciszewska, M. Z.; Barciszewski, J. Suppression of human brain tumor with interference RNA specific for tenascin-C. Cancer Biol. Ther., 2006, 5 (8), 1002-1007.

[118] Rolle, K.; Nowak, S.; Wyszko, E.; Nowak, M.; Zukiel, R.; Piestrzeniewicz, R.; Gawronska, I.; Barciszewska, M. Z.; Barciszewski, J. Promising human brain tumors therapy with interference RNA intervention (iRNAi). Cancer Biol. Ther., 2010, 9 (5), 396-406.

[119] Engstrom, Y.; Eriksson, S.; Jildevik, I.; Skog, S.; Thelander, L.; Tribukait, B. Cell cycle-dependent expression of mammalian ribonucleotide reductase. Differential regulation of the two subunits. $J$. Biol. Chem., 1985, 260 (16), 9114-9116.

[120] Heidel, J. D.; Liu, J. Y.; Yen, Y.; Zhou, B.; Heale, B. S.; Rossi, J. J.; Bartlett, D. W.; Davis, M. E. Potent siRNA inhibitors of ribonucleotide reductase subunit RRM2 reduce cell proliferation in vitro and in vivo. Clin. Cancer Res., 2007, 13 (7), 2207-2215.

[121] Duxbury, M. S.; Ito, H.; Zinner, M. J.; Ashley, S. W.; Whang, E. E. RNA interference targeting the M2 subunit of ribonucleotide reductase enhances pancreatic adenocarcinoma chemosensitivity to gemcitabine. Oncogene, 2004, 23 (8), 1539-1548.

[122] Davis, M. E.; Pun, S. H.; Bellocq, N. C.; Reineke, T. M.; Popielarski, S. R.; Mishra, S.; Heidel, J. D. Self-assembling nucleic acid delivery vehicles via linear, water-soluble, cyclodextrin-containing polymers. Curr. Med. Chem., 2004, 11 (2), 179-197.

[123] Heidel, J. D. Linear cyclodextrin-containing polymers and their use as delivery agents. Expert. Opin. Drug Deliv., 2006, 3 (5), 641-646.

[124] Clinical trials. A service of the U.S. National Institutes of Health. http://clinicaltrials.gov/ct2/home (Accessed January 5, 2013).

[125] Aleku, M.; Schulz, P.; Keil, O.; Santel, A.; Schaeper, U.; Dieckhoff, B.; Janke, O.; Endruschat, J.; Durieux, B.; Roder, N.; Loffler, K.; Lange, C.; Fechtner, M.; Mopert, K.; Fisch, G.; Dames, S.; Arnold, W.; Jochims, K.; Giese, K.; Wiedenmann, B.; Scholz, A.; Kaufmann, J. Atu027, a liposomal small interfering RNA formulation targeting protein kinase N3, inhibits cancer progression. Cancer Res., 2008, 68 (23), 9788-9798.

[126] Santel, A.; Aleku, M.; Roder, N.; Mopert, K.; Durieux, B.; Janke, O.; Keil, O.; Endruschat, J.; Dames, S.; Lange, C.; Eisermann, M.; Loffler, K.; Fechtner, M.; Fisch, G.; Vank, C.; Schaeper, U.; Giese, K.; Kaufmann, J. Atu027 prevents pulmonary metastasis in experimental and spontaneous mouse metastasis models. Clin. Cancer Res., 2010, 16 (22), 5469-5480.

[127] Leenders, F.; Mopert, K.; Schmiedeknecht, A.; Santel, A.; Czauderna, F.; Aleku, M.; Penschuck, S.; Dames, S.; Sternberger, M.; Rohl, T.; Wellmann, A.; Arnold, W.; Giese, K.; Kaufmann, J.; Klippel, A. PKN3 is required for malignant prostate cell growth downstream of activated PI 3-kinase. EMBO J., 2004, 23 (16), 3303-3313. [110a]

[128] Strumberg, D.; Schultheis, B.; Traugott, U.; Vank, C.; Santel, A.; Keil, O.; Giese, K.; Kaufmann, J.; Drevs, J. Phase I clinical development of Atu027, a siRNA formulation targeting PKN3 in patients with advanced solid tumors. Int. J. Clin. Pharmacol. Ther., 2012, 50 (1), 76-78.

[129] Blangy, A.; Lane, H. A.; d'Herin, P.; Harper, M.; Kress, M.; Nigg, E. A. Phosphorylation by $\mathrm{p} 34 \mathrm{cdc} 2$ regulates spindle association of human Eg5, a kinesin-related motor essential for bipolar spindle formation in vivo. Cell, 1995, 83 (7), 1159-1169.

[130] Kinch, M. S.; Moore, M. B.; Harpole, D. H., Jr. Predictive value of the EphA2 receptor tyrosine kinase in lung cancer recurrence and survival. Clin. Cancer Res., 2003, 9 (2), 613-618.

[131] Noblitt, L. W.; Bangari, D. S.; Shukla, S.; Knapp, D. W.; Mohammed, S.; Kinch, M. S.; Mittal, S. K. Decreased tumorigenic potential of EphA2-overexpressing breast cancer cells following treat- 
ment with adenoviral vectors that express EphrinA1. Cancer Gene Ther., 2004, 11 (11), 757-766.

[132] Abraham, S.; Knapp, D. W.; Cheng, L.; Snyder, P. W.; Mittal, S. K.; Bangari, D. S.; Kinch, M.; Wu, L.; Dhariwal, J.; Mohammed, S. I. Expression of EphA2 and Ephrin A-1 in carcinoma of the urinary bladder. Clin. Cancer Res., 2006, 12 (2), 353-360.

[133] Nakamura, R.; Kataoka, H.; Sato, N.; Kanamori, M.; Ihara, M.; Igarashi, H.; Ravshanov, S.; Wang, Y. J.; Li, Z. Y.; Shimamura, T.; Kobayashi, T.; Konno, H.; Shinmura, K.; Tanaka, M.; Sugimura, H. EPHA2/EFNA1 expression in human gastric cancer. Cancer Sci., 2005, 96 (1), 42-47.

[134] Landen, C. N.; Kinch, M. S.; Sood, A. K. EphA2 as a target for ovarian cancer therapy. Expert. Opin. Ther. Targets., 2005, 9 (6), 1179-1187.

[135] Yang, X. Z.; Dou, S.; Sun, T. M.; Mao, C. Q.; Wang, H. X.; Wang, J. Systemic delivery of siRNA with cationic lipid assisted PEGPLA nanoparticles for cancer therapy. J. Control Release, 2011, $156(2)$, 203-211.

[136] Tekmira Pharmaceutical Corporations. http://www.tekmirapharm. com/Programs/Products.asp (Accessed January 5, 2013).

[137] Kitada, S.; Andersen, J.; Akar, S.; Zapata, J. M.; Takayama, S.; Krajewski, S.; Wang, H. G.; Zhang, X.; Bullrich, F.; Croce, C. M.; Rai, K.; Hines, J.; Reed, J. C. Expression of apoptosis-regulating proteins in chronic lymphocytic leukemia: correlations with In vitro and In vivo chemoresponses. Blood, 1998, 91 (9), 3379-3389.

[138] Sengupta, A.; Banerjee, D.; Chandra, S.; Banerjee, S. Gene therapy for BCR-ABL+ human CML with dual phosphorylation resistant p27Kip1 and stable RNA interference using an EBV vector. $J$. Gene Med., 2006, 8 (10), 1251-1261.

[139] Chapman, C. M.; Sun, X.; Roschewski, M.; Aue, G.; Farooqui, M.; Stennett, L. S.; Gibellini, F.; Arthur, D.; Perez-Galan, P.; Wiestner, A. ON 01910.Na is selectively cytotoxic for Chronic Lymphocytic Leukemia cells through a dual mechanism involving PI3K/AKT inhibition and induction of oxidative stress. Clin. Cancer Res., 2012, 18 (7), 1979-1991.

[140] Jakowlew, S. B.; Mathias, A.; Chung, P.; Moody, T. W. Expression of transforming growth factor beta ligand and receptor messenger RNAs in lung cancer cell lines. Cell Growth Differ., 1995, 6 (4), 465-476.

[141] Phadke, A. P.; Jay, C. M.; Wang, Z.; Chen, S.; Liu, S.; Haddock, C.; Kumar, P.; Pappen, B. O.; Rao, D. D.; Templeton, N. S.; Daniels, E. Q.; Webb, C.; Monsma, D.; Scott, S.; Dylewski, D.; Frieboes, H. B.; Brunicardi, F. C.; Senzer, N.; Maples, P. B.; Nemunaitis, J.; Tong, A. W. In vivo safety and antitumor efficacy of bifunctional small hairpin RNAs specific for the human Stathmin 1 oncoprotein. DNA Cell Biol., 2011, 30 (9), 715-726.
Received: October 01, 2012

Revised: January 11, 2013

Accepted: January 30, 2013 